\title{
Young sea turtles of the pelagic Sargassum-dominated drift community: habitat use, population density, and threats
}

\author{
Blair Witherington ${ }^{1, *}$, Shigetomo Hirama ${ }^{1}$, Robert Hardy ${ }^{2,3}$ \\ ${ }^{1}$ Fish and Wildlife Research Institute, Florida Fish and Wildlife Conservation Commission, 9700 South A1A, Melbourne Beach, \\ Florida, USA \\ ${ }^{2}$ Fish and Wildlife Research Institute, Florida Fish and Wildlife Conservation Commission, 100 Eighth Avenue, St. Petersburg, \\ Florida, USA \\ ${ }^{3}$ College of Marine Science, University of South Florida, 140 Seventh Avenue, South, St. Petersburg, Florida 33701, USA
}

\begin{abstract}
In the western Atlantic young sea turtles in their surface-pelagic juvenile stage, a stage often described as the lost year(s), have been hypothesized to occupy habitat dominated by pelagic Sargassum macroalgae. But despite substantial indirect evidence, there has been no direct study of sea turtles within this community. To determine the importance of Sargassum to young sea turtles, we transected surfacepelagic habitat, measured relative abundance of sea turtles, recorded their behavior and association with surface features, and assessed their diet. On vessel transects in the eastern Gulf of Mexico and Atlantic Ocean off Florida (USA), we recorded 1884 turtles of 4 species-loggerhead sea turtle Caretta caretta, green turtle Chelonia mydas, hawksbill Eretmochelys imbricata, and Kemp's ridley Lepidochelys kempii. Most (89\%) were initially observed within $1 \mathrm{~m}$ of floating Sargassum. Turtles included both post-hatchlings (39 to $78 \mathrm{~mm}$ straight carapace length, SCL) and juveniles (130 to $280 \mathrm{~mm}$ SCL). Dive-profile data from overnight logs (18.5 to $23.1 \mathrm{~h}$ duration) of 3 juvenile Kemp's ridleys showed that they spent an average of $97 \%$ (day) or $87 \%$ (night) of their time within $1 \mathrm{~m}$ of the surface. Juvenile turtles from which esophageal lavage and fecal samples were obtained showed a diet composed principally of Sargassum-community associates, primarily marine animals. Other items included marine plants (predominantly pelagic Sargassum), synthetic material (e.g. plastics), terrestrial plants (mostly wood), and terrestrial animals (flying insects). Plastics in diet samples averaged $13 \%$ of dry mass. Data support a description of pelagic Sargassum as a transient hot spot for young sea turtles and a focal point for threats, including debris ingestion and petroleum.
\end{abstract}

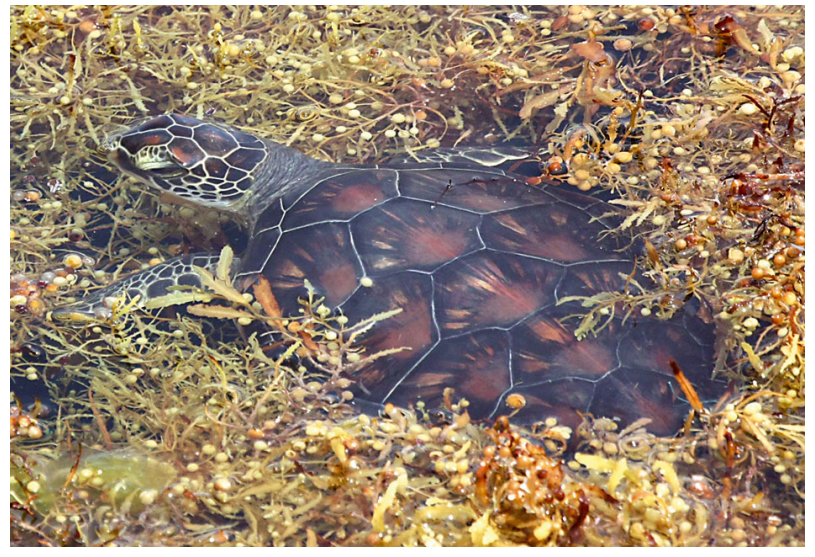

A juvenile green turtle Chelonia mydas within a convergent line of pelagic Sargassum macroalgae in the eastern Gulf of Mexico

Photo: Blair Witherington

KEY WORDS: Caretta caretta - Chelonia mydas . Eretmochelys imbricata . Lepidochelys kempii . Oceanic juvenile · Plastics ingestion · Oil · Diet · Behavior

Resale or republication not permitted without written consent of the publisher

\section{INTRODUCTION}

Conserving sea turtles inhabiting the open sea is challenging, in part due to difficulties in identifying remote habitats. In deep, epipelagic waters, sea turtle habitats are transitory and cannot be completely described by spatial information. To guide habitat- 
protection efforts and conservation planning for sea turtles, we measured the importance of surfacepelagic habitat occupied by post-hatchling and early juvenile sea turtles in the western North Atlantic and Gulf of Mexico. In 2010, assessments of sea turtle habitat use in the Gulf of Mexico were shown to be critically lacking when Gulf waters received the largest offshore oil spill ever recorded (Camilli et al. 2010, Bjorndal et al. 2011). Spill-response (turtle rescue) data (NOAA 2012a) show that this spill was particularly harmful to the sea turtle life stage and surface-pelagic habitat we describe here.

Each of the 6 sea turtle species found in the Atlantic Ocean, Caribbean Sea, and Gulf of Mexico has a juvenile stage thought to be distributed almost exclusively in open-sea habitats (Bolten 2003a). In this paper, we use the term 'surface-pelagic' to describe the life stage referred to by Bolten as 'oceanic,' recognizing that the turtles' distribution, although wholly epipelagic, extends into deep-neritic waters. We provide further treatment of this terminology in the 'Discussion'.

\section{Sea turtles' lost year(s)}

The early surface-pelagic life stages of sea turtles are poorly known. Sufficient empirical evidence for confident conclusions about surface-pelagic distribution and ecology as juveniles is available for only 1 species, the loggerhead sea turtle Caretta caretta. Loggerhead juveniles have been directly sampled in situ, including captures of post-hatchlings off nesting beaches (Witherington 2002) and captures of large juveniles (mostly 150 to $550 \mathrm{~mm}$ straight carapace length, SCL) foraging in the open sea (Carr 1986, Bolten 2003b, McCarthy et al. 2010). These studies have provided empirical information on behavior, habitat associations, and diet specific to an occupied habitat. For the largest surface-pelagic juvenile loggerheads (500 to $700 \mathrm{~mm} \mathrm{SCL}$ ), researchers have used satellite telemetry and remote sensing to identify coarse features of habitat traversed by turtles in the Central Pacific (Polovina et al. 2006, Howell et al. 2008) and in the eastern North Atlantic (Bolten 2003b, McCarthy et al. 2010).

Loggerhead sea turtles and 3 additional species are best known within coastal/neritic waters where older immature turtles and adults are found (Musick \& Limpus 1997, McClellan \& Read 2007, Mansfield et al. 2009). The 3 additional species are the green turtle Chelonia mydas, hawksbill Eretmochelys imbricata, and Kemp's ridley Lepidochelys kempii.
Although large juveniles of these species are commonly captured for study in shallow-water habitats, young juveniles $(<250 \mathrm{~mm} \mathrm{SCL})$ from the open sea are poorly represented by empirical observations in situ.

Given the persistent difficulty in understanding their juvenile life stage, green turtles, hawksbills, and Kemp's ridleys epitomize the original description of this developmental period as the 'lost year(s)' (Carr et al. 1978). The term remains in use (Reich et al. 2007) and most often refers to the smallest (youngest) juveniles, which are inaccessible due to their absence from coastal waters. Citing this absence, hypotheses about the distribution of juvenile green turtles, hawksbills, and Kemp's ridleys have focused on open-sea habitats (Bolten 2003a).

The distribution of juvenile sea turtles in the open sea is reasoned to match the patchy, widely scattered, and spatiotemporally dynamic distribution of the resources they depend on (Polovina et al. 2000). As air-breathing animals with limited diving depth and a low swimming speed, small turtles would be challenged to move frequently between resource patches. Unlike seabirds (Weimerskirch 2007), young sea turtles would seem to be obligated to live near the patchy areas where they forage. These patches are often defined by surface advection and convergence, oceanographic forces that offer foraging turtles benefits from resource renewal and recombination. In addition, turtles occupying these patches for extended periods would receive passive transport on a potentially large scale.

At least 2 categories of foraging patches have been proposed for surface-pelagic juvenile sea turtles. The first includes areas of elevated surface chlorophyll where upwelling provides nutrients for localized increases in productivity (Polovina et al. 2004). A second category includes surface-pelagic convergence zones ranging in extent from fronts at the edges of major surface currents to small-scale windrows generated by Langmuir cells (Polovina et al. 2000, 2004, 2006, Witherington 2002, Howell et al. 2008, 2010, Kobayashi et al. 2008). These convergence zones commonly accumulate drifting neustonic organisms and are characterized by lines of floating material with occasionally elevated surface chlorophyll (Thiel \& Gutow 2005a,b). In the North Atlantic, convergence zones are frequently traced by conspicuous lines of the pelagic brown algae Sargassum natans and S. fluitans (Butler et al. 1983, Butler \& Stoner 1984).

Hornell (1927) first recorded young sea turtles floating within seaweed rafts, in an observation of post- 
hatchling hawksbills in the Indian Ocean. But the hypothesis linking early juvenile-stage sea turtles to convergence zones, the drift community, and pelagic Sargassum was first expressed in detail by Carr \& Meylan (1980). This Sargassum rafting hypothesis was later addressed with an extensive treatment of circumstantial evidence by Carr (1987). Carr's review outlined anecdotal observations of turtles at sea and records of turtles found within the stomachs of pelagic fishes or stranded following storms. The stranded turtles had commonly washed ashore along with masses of pelagic Sargassum or were recorded to have Sargassum associates or other neustonic organisms in their gut. Despite the well-founded Sargassum-association hypothesis offered by Carr, there has been no systematic, direct study of sea turtles within the pelagic Sargassum community, other than research targeting the post-hatchling stage of the loggerhead sea turtle (Witherington 2002).

Because of difficulty in accessing juvenile sea turtles during their surface-pelagic stage, research has turned to indirect methods. A growing body of research has focused on the trophic record carried by older turtles, as revealed by stable isotope proportions in their tissues. These records allow inference on generalized trophic links between young sea turtles and forage organisms (Tomas et al. 2001, Reich et al. 2007, Arthur et al. 2008). In turn, these links imply suites of possible habitat characteristics. Without detail from empirical evidence, however, conclusions about juvenile habitat and its use have lacked reliability. Tomas et al. (2001) and Reich et al. (2007) cite the difficulty in obtaining ecological information on this life-history stage via direct in situ observation. Also citing this difficulty, researchers describing the behavior of surface-pelagic turtles have turned to experiments with captive turtles to measure habitat choice in laboratory settings (Mellgren et al. 2003, Smith \& Salmon 2009).

\section{The Sargassum-dominated surface-pelagic drift community}

Pelagic Sargassum is a rugged, highly branched alga buoyed by pneumatocysts and lacking holdfasts. Individual plant clumps are usually $<80 \mathrm{~cm}$ across, although clumps can form mats hundreds of meters wide and lines that are 10s of kilometers long (Butler et al. 1983). The 2 principal species, S. natans (most common) and S. fluitans, are holopelagic and are substrate for a variety of animals that are obligate Sargassum associates thought to have evolved from benthic ancestors (see review by Coston-Clements et al. 1991). Surface convergence zones assemble pelagic Sargassum, as well as other macroalgal species, vascular plants (including woody stems and seeds), animal remains, volcanic pumice, buoyant sediment (foam), and anthropogenic debris (especially tar and plastics) (Thiel \& Gutow 2005a). Hundreds of animal species are associates of this surface drift community (Dooley 1972, Butler et al. 1983). The majority of pelagic Sargassum biomass drifts within the western North Atlantic, Caribbean Sea, and Gulf of Mexico between the latitudes of 20 and $40^{\circ} \mathrm{N}$ (Butler et al. 1983, Butler \& Stoner 1984). Within this region, pelagic Sargassum is a tracer for patches of high productivity and structure amid areas of low primary productivity and minimal structure (Butler et al. 1983).

For this study, we hypothesized that the pelagic Sargassum drift community formed the principal habitat for surface-pelagic juvenile sea turtles in the western North Atlantic and Gulf of Mexico. To test this hypothesis, we conducted searches along transects within and outside this community, recorded the behavior of observed turtles and their association with Sargassum patches, and recorded diet items from a set of captured turtles. We quantified relative densities of juvenile turtles in surface-pelagic habitat using line-transect distance-sampling methods. We describe these habitats using first-hand observations of turtles and remotely sensed observations of the sea-surface environment.

We further hypothesized that pelagic Sargassum plays a dominant ecological role in sea turtle development within the region. To test this hypothesis we measured diet and behavior relative to Sargassum community associates and individual patches of pelagic Sargassum.

\section{MATERIALS AND METHODS}

\section{Study areas and research vessels}

We conducted searches for surface-pelagic sea turtles using one of two $6.5 \mathrm{~m}$ single-keel power vessels (1992 to 2002, RV 'Excellent Fishe I and II') and an $8.2 \mathrm{~m}$ power catamaran (2003 to 2011, RV 'Excellent Fishe III'), launched at 8 ports along Florida's Atlantic and Gulf of Mexico coasts (Fig. 1). Because of differing vessel configurations, observer placement was not constant. However, each search took place with at least 2 observers (maximum, 4). Each observer had a $360^{\circ}$ view of the surrounding water, with principal 


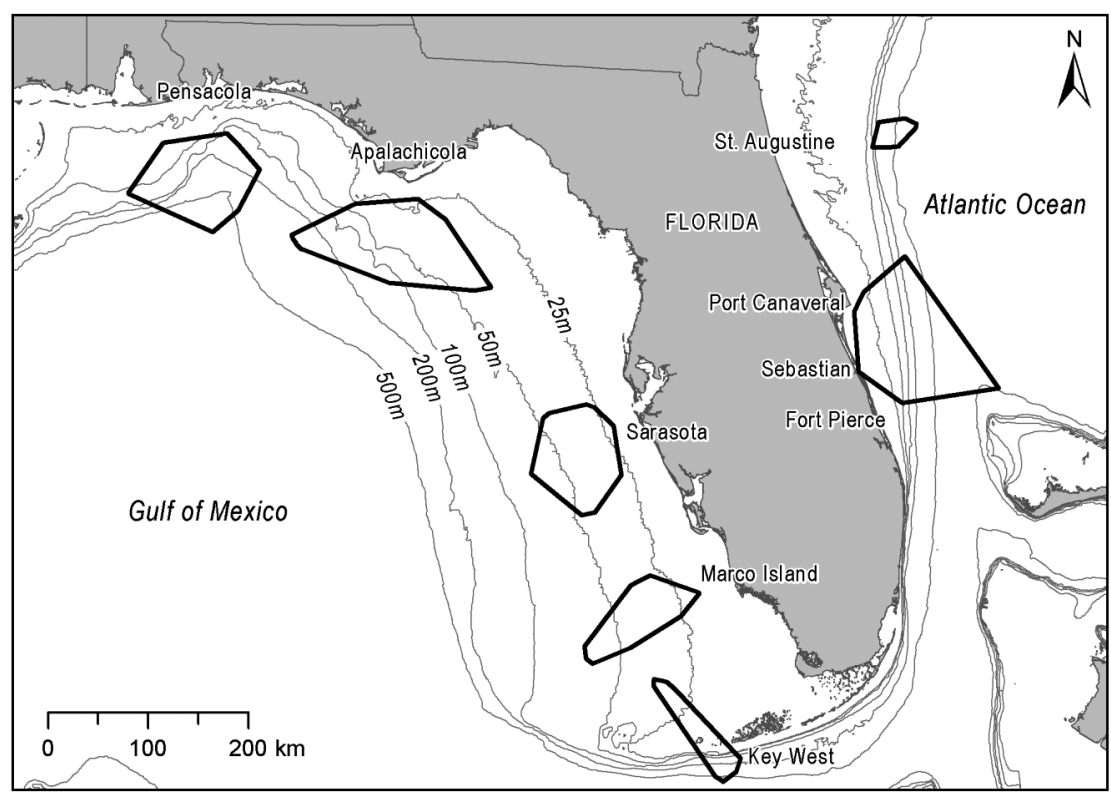

Fig. 1. Areas searched for surfacepelagic sea turtles off Florida (USA) ports, from 1992 to 2011. Boundaries mark minimum convex polygons encompassing all search transects, which were conducted through patches of consolidated floating material dominated by pelagic Sargassum attention focused forward. Searches were conducted within patches of consolidated floating material (mats, scattered patches, and drift lines) and between these patches. Between 1992 and 2004, we searched in the Atlantic Ocean near the western Florida Current from the Florida ports of Sebastian Inlet, Port Canaveral, and Fort Pierce Inlet (Fig. 1). Between 2005 and 2011, we sampled both Atlantic Ocean and Gulf of Mexico locations from ports including Sebastian Inlet, Port Canaveral, St. Augustine, Key West, Marco Island, Sarasota, Apalachicola, and Pensacola (Fig. 1). Offshore trips were made from May to October when calm sea states (Beaufort force 0 to 3 ) and weather conditions were suitable for observing small turtles and floating material. (Wind disperses floating material and creates choppy surface water that hinders turtle observation.)

\section{Search effort, captures, and turtle data collected}

We conducted searches for turtles along course lines extending offshore from each port approximately perpendicular to the coastline. Upon reaching an area where there was consolidated floating material, we changed vessel course to run the vessel through the drift material, which was commonly oriented in linear rows. We conducted searches by maintaining our vessel's course through the greatest visible concentration of material. These searches resulted in curvilinear transects that accommodated windrows in interrupted offset lines. Large mats $>10 \mathrm{~m}$ across (rare) were searched along 2 parallel transects. Each concentration of drift material was characterized as being an individual mat, a continuous line, broken windrows, or scattered patches.

We timed search transects through drift material, and vessel speed relative to surrounding water, bearing, and transect path over ground (from Wide Area Augmentation System, WAAS, GPS) were recorded automatically each minute during transect searches. For each transect searched in currents of $<1 \mathrm{~km} \mathrm{~h}^{-1}$ speed, distance over water was calculated using the path recorded by the GPS. In areas with a more rapid current, distance over water was measured using vessel speed and search time. During search transects, the vessel maintained a bearing away from the transect start point so that double-counting turtles within the searched area would be unlikely (mean vessel speed $=6.4 \mathrm{~km} \mathrm{~h}^{-1}$ ). It is possible that a small number of turtles not captured (tagged) were doublecounted, but the average distance between successive observations, the inactivity of most turtles, and the lack of recaptures of marked animals suggest that double-counting within each sampling day was negligible.

In addition to searches along transects within drift material, we also searched opportunistically as the vessel traveled offshore and between patches of drift material. These vessel paths were also recorded by GPS. We distinguished between target areas and non-target areas: Target areas were linear patches of drift material, and non-target areas were all other areas searched. Searches through non-target areas were commonly in open water, although these areas occasionally had thinly scattered floating material. 
When a turtle was observed, we recorded its geographic position and measured its distance from the vessel along a line perpendicular to the vessel's path using a digital inclinometer or graduated marks on the pole of the capture dip net. In the case of inclinometer measurements, we determined the sighting angle $\theta$ and calculated distance using the average observer's eye height above water (typically 3 to $4 \mathrm{~m}$ ) divided by $\tan \theta$. In the case of distances measured with the graduated pole (length $=4 \mathrm{~m}$ ), distances beyond the pole's length were estimated using pole graduations as a reference. Where the initial location of an observed turtle and its distance from the vessel were uncertain, no measurement was recorded.

Additional data recorded for turtles at the moment they were first observed included time, behavior, distance from the closest floating object, and identity of the closest floating object. Turtles first observed during rapid dives or while swimming away from the vessel were categorized as having responded to the observer's presence and were not used in analyses of behavior. We divided initial behavior between 5 categories:

(1) Inactive: including turtles floating with flippers held away from the body and turtles in a 'tuck' position - ventral surface of each front flipper is pressed flat against the lateral carapace and the rear flippers overlap posterior to the tail.

(2) Breath: including turtles at the surface with head raised (and on closest examination, with inflated buccal-pharyngeal region) and little other movement, and turtles in a 'dogpaddle' — the head is raised and there are alternating, circular movements of all flippers.

(3) Slow swim: including turtles with sluggish movement of the front flippers, turtles using a 'rearflipper kick' - ventral surface of each front flipper is pressed flat against the lateral carapace and the rear flippers make repeated simultaneous swimming strokes, and undetermined surface movement wherein floating turtles show some water movement although their flippers are not observed. In each slow-swim behavior, the carapace remains partially above the water's surface.

(4) Subsurface swim: including turtles that are 'powerstroking' — the turtle swims horizontally using front-flipper strokes, and turtles in a 'dive,' whereby the turtle swims vertically (upward or downward) using front-flipper strokes.

(5) Contact (front-flipper) movement: including turtles moving their head within a mass of floating material or manipulating that material with their front flippers. Head movements were consistent with feeding. Turtles moving their flippers were typically parting the floating material in front of them. In this category we included 'crawling,' in which the turtle moves on floating material with alternating flipper movements similar to the gait used by hatchlings on the beach.

The approximate distance between a turtle and the nearest floating object was assigned to 1 of 3 categories: touching $(0 \mathrm{~m})$, near (within $1 \mathrm{~m})$, and distant $(>1 \mathrm{~m})$. The nearest floating object was identified by general category such as Sargassum, seagrass leaf, seagrass rhizome, or plastic.

Where possible, we captured turtles using a longhandled $(4 \mathrm{~m})$ dip net. The information recorded for each captured turtle included health condition, injuries, SCL (measured from the nuchal notch to the longest pygal tip), mass, and evidence of plastic and tar ingestion from examination of the mouth.

For an assessment of post-hatchling growth since recruitment from the nesting beach, we measured SCL and body mass in 5 loggerhead hatchlings from each of 65 nests $(n=325)$ distributed among the most densely nested beaches on Florida's Atlantic coast (28.1 to $26.3^{\circ} \mathrm{N}$ ). These measurements were made in August 2001 and included hatchlings from in situ and hatchery nests (approximately 1:1).

\section{Diving behavior}

To gather additional information on behavior and habitat use, we tracked 4 juvenile Kemp's ridleys for periods ranging from 18.5 to $23.1 \mathrm{~h}$. Tracking was facilitated by an acoustic tag (Sonotronics AST-05) attached to each turtle; the tags logged time, temperature, and depth. AST-05 tags were fitted to turtles with a harness made of weak latex straps (breaking strength $=2 \mathrm{~kg}$ ) secured around the carapace just anterior to the widest point. The harness held the AST-05 tightly to the turtle's plastron and bore a small foam float that made the combination neutrally buoyant (total mass $=50 \mathrm{~g}$ ). The combination harness was adjusted to be hydrodynamic and have low potential for becoming entangled in Sargassum or debris. Deterioration of the thin latex straps would release the harness if the turtle could not be recaptured. We captured and released turtles within 20 min at the floating material marking the location where they were originally observed.

We approximated the locations of tracked turtles by recording signal strength and direction of the acoustic tag through a directional hydrophone (Sonotronics DH-4) and receiver (USR-96). Locations were 
logged approximately every 20 min with the tracking vessel's GPS for 'close' signal strengths (estimated distance within $300 \mathrm{~m}$ from the turtle). 'Close' distances correlated with strong sonic signals that were minimally directional (isotropic) and were verified by periodic triangulation of points.

The AST-05 recorded each turtle's depth at $6 \mathrm{~s}$ intervals with a resolution of $3 \mathrm{~cm}$. When the tracking episode was concluded, we relocated the tracked turtle by the acoustic tag's signal and recaptured the turtle by dip net. Time and depth data were downloaded from the AST-5 upon retrieval.

\section{Esophageal lavage and fecal collection for determination of diet composition}

Between 2006 and 2011 we collected diet material from a subsample of captured turtles. Recently ingested material was flushed from turtles by esophageal lavage immediately after capture. We used a lavage technique similar to that of Forbes (1999), with modifications including use of small-diameter ( $7 \mathrm{~mm}$ ) silicone tubing. Flushed items were strained with a $500 \mu \mathrm{m}$ filter net and preserved in $70 \%$ ethanol for later examination.

After the esophageal lavage, we allowed a subsample of turtles to sit approximately $30 \mathrm{~min}$ in clean plastic bins so that their feces could be collected. Fecal collection followed the lavage procedure in order to capitalize on the gastrocolic response initiated by the lavage. Feces were collected with a rubber spatula and preserved in jars of $70 \%$ ethanol.

Both lavage items and fecal contents were identified under a binocular dissecting microscope to the lowest possible taxon or object grouping. We then divided items between sample lots of animal, plant, and synthetic material and dried each sample lot in a drying oven for $24 \mathrm{~h}$. Each sample was then weighed to the nearest $0.01 \mathrm{mg}$ using an Ohaus DV215CD analytical balance.

\section{Remote sensing data and GIS}

We used remotely sensed oceanographic data products to search for associations between observed turtle locations and conspicuous sea-surface features (e.g. frontal boundaries). Remotely sensed sea surface temperature (SST), chlorophyll $a$, and altimeter data came from the NOAA Coast Watch Caribbean/ Gulf of Mexico Regional Node (NOAA 2012b). We also examined higher resolution Landsat satellite imagery coinciding with sampling trips in order to identify habitat features. Surface-pelagic habitat was identified using $30 \mathrm{~m}$ resolution Landsat (5 TM and 7 ETM) imagery. The Landsat scenes were selected and downloaded via the Global Visualization Viewer maintained by the US Geological Survey (USGS 2012). We also generated floating algae index (FAI) images from Landsat's raw reflectance data using the methods described by $\mathrm{Hu}$ (2009).

\section{Distance data and modeling}

Because of uniformity in search-vessel configuration, search methods, and observer personnel from 2005 to 2011, we restricted our analysis of distance data to this period. We modeled detectability functions (Buckland et al. 1993) for turtles observed during transects through consolidated floating material, such that each set of transects surveyed on a single search day served as a line transect. Each day had search effort within target areas and non-target areas. The distances of turtles from that trackline (a set of continuous data) were modeled using the program Distance 6.0 (Thomas et al. 2009). Each model fit the associated distance data based on insignificant (alpha $=0.05$ ) Cramér-von Mises goodness-of-fit tests with a cosine weighting function.

Total individual transect lengths for each day were used by the 'Distance' program to calculate relative densities of turtles within the habitat surveyed. Habitat surveyed included surface waters that could be observed from the vessel trackline, which was guided by the densest accumulation of floating material, principally Sargassum spp. During transects, observable water included both areas between Sargassum patches and areas lateral to linear accumulations, which contained Sargassum at low densities.

We divided our study areas (Fig. 1) between 2 geographic strata, Gulf of Mexico and Atlantic, and we divided turtle observations between 2 life-stage strata, post-hatchling ( $<100 \mathrm{~mm}$ SCL) and juvenile (>100 mm SCL). Only transects conducted during the regional sea turtle hatching season (July to October) were counted as effort (transect length) for the posthatchling analysis. We observed no post-hatchlings outside this period.

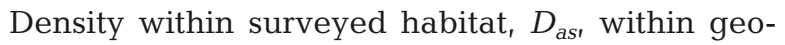
graphic stratum $a$ and life-stage $s$, was estimated by:

$$
D_{a s}=\left[n_{a s} \times f(0)\right] /\left[2 \times L_{a} \times g(0)\right]
$$

where $n_{a s}$ is the number of observed turtles within area $a$ and of life stage $s, f(0)$ is the sighting probabil- 
ity density at zero distance, $L_{a}$ is the total length of transect within area $a$, and $g(0)$ is the probability of observing a turtle directly on the vessel trackline (Williams et al. 2002).

We estimated $f(0)$ using options for hazard-rate and half-normal key functions, each with cosine adjustment, using the program Distance 6.0 (Thomas et al. 2009). For all strata, the half-normal detection model provided the best fit based on Akaike's information criterion (AIC, employed within Distance 6.0). A value for $g(0)$ came from 2 sources of information that varied between the 2 life stages considered. Based on behavioral observations of each group, we assumed that values for $g(0)$ were close to 1 . However, we adjusted this value for juvenile turtles based on the average surface-time estimates calculated from the juvenile Kemp's ridley dive data.

\section{RESULTS}

\section{Sampling effort, and species and life stages observed}

From 1992 through 2011, we conducted 154 trips into the Atlantic Ocean and Gulf of Mexico off Florida to locate surface-pelagic sea turtles. The number of trips by port of departure was: Pensacola, 6; Apalachicola, 14; Sarasota, 20; Marco Island, 5; Key West, 4; Sebastian Inlet, 47; Port Canaveral, 56; and St. Augustine, 2 (Fig. 1). During these trips we observed 1884 turtles. Most of these (1704) were <100 mm SCL and were considered to be post-hatchlings or young-of-the-year (Fig. S1 in the supplement at www.int-res.com/articles/ suppl/m463p001_supp.pdf). Captured post-hatchlings ranged in size between 39 and $78 \mathrm{~mm}$ SCL and were observed only during the hatching season of adjacent nesting beaches in Florida (July to October). Most post-hatchling turtles were loggerhead sea turtles $(\mathrm{n}=1688)$; the remaining post-hatchlings were green turtles $(n=15)$. One post-hatchling was not identified to species. Most post-hatchlings ( $\mathrm{n}=1673$ ) were observed in the Atlantic, and the remainder $(n=31)$ were observed in the Gulf of Mexico off the principal nesting beaches of southwestern Florida (Witherington et al. 2009).
We observed a size distribution of juvenile sea turtles that did not overlap with the sizes of turtles we considered to be post-hatchlings. These 179 juvenile turtles ranged in size between 130 and $280 \mathrm{~mm}$ SCL and comprised 4 species: green turtle $(\mathrm{n}=89)$, Kemp's ridley $(\mathrm{n}=74)$, hawksbill $(\mathrm{n}=6)$, and loggerhead ( $\mathrm{n}=5$ ) (Fig. S1). Five juveniles were not identified to species. We recorded the majority of these turtles (172 of 179) during trips into the Gulf of Mexico. Because our trips into the Gulf began only in 2005, most of our records of surface-pelagic juveniles were collected from 2005 through 2011.

\section{Post-hatchling turtles captured}

We captured and measured 1369 surface-pelagic loggerheads of post-hatchling size (Fig. 2). The posthatchling loggerheads captured in the Gulf of Mexico and in the Atlantic off St. Augustine were significantly larger than those captured in the Atlantic south of St. Augustine, as indicated by respective $t$-tests of means (all p $<0.001$, Table 1). Distances of captures from the closest nesting beach averaged $45 \mathrm{~km}$ for Atlantic captures south of St. Augustine and 110 and $87 \mathrm{~km}$, respectively, for captures off St. Augustine and in the Gulf of Mexico. For compari-

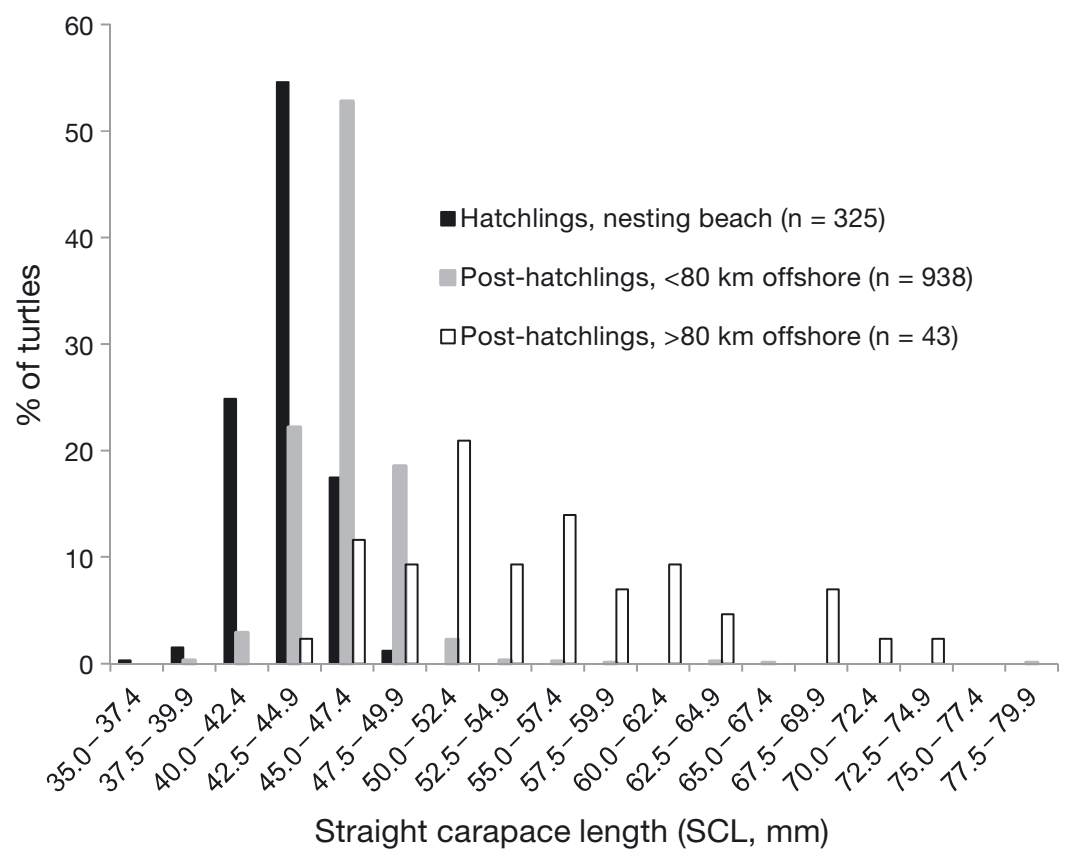

Fig. 2. Caretta caretta. Size frequencies of hatchling and post-hatchling loggerhead sea turtles. Hatchlings were collected on nesting beaches of Florida's Atlantic coast. Post-hatchlings were captured from locations that differed in their distance from land. Locations $<80 \mathrm{~km}$ offshore were located in the Atlantic Ocean off southeastern Florida, and locations $>80 \mathrm{~km}$ offshore were located in the Atlantic off St. Augustine or in the Gulf of Mexico 
Table 1. Caretta caretta. Straight carapace length (SCL) and body mass (BM) of hatchling and post-hatchling loggerhead sea turtles. Post-hatchlings were captured from the Gulf of Mexico and Atlantic Ocean off Florida. Capture locations differed in their distance from the closest nesting beaches. Post-hatchlings from waters of the Gulf of Mexico and Atlantic Ocean off St. Augustine were captured $>80 \mathrm{~km}$ from land. Post-hatchlings from Atlantic waters south of St. Augustine (off Port Canaveral, Sebastian Inlet, Fort Pierce) were captured $<80 \mathrm{~km}$ from land. Hatchlings were collected on nesting beaches of Florida's Atlantic coast

\begin{tabular}{|lccc|}
\hline Turtles sampled & $\mathrm{n}$ & $\begin{array}{c}\text { Straight carapace length } \\
\text { (mean } \pm \text { SD, mm) }\end{array}$ & $\begin{array}{c}\text { Body mass } \\
\text { (mean } \pm \text { SD, g) }\end{array}$ \\
\hline Post-hatchlings, Gulf of Mexico & 30 & $57.1 \pm 7.3$ & $39.9 \pm 14.1$ \\
Post-hatchlings, Atlantic off St. Augustine & 13 & $51.5 \pm 6.4$ & $32.6 \pm 10.2$ \\
Post-hatchlings, Atlantic south of St. Augustine & 1326 (SCL) & $46.1 \pm 2.5$ & $22.1 \pm 3.1$ \\
& 813 (BM) & $43.4 \pm 1.9$ & $18.2 \pm 1.9$ \\
Hatchlings, Atlantic beaches & 325 & & \\
\hline
\end{tabular}

son, hatchling loggerheads directly from nests on Atlantic Florida beaches between 28.1 and $26.3^{\circ} \mathrm{N}$ averaged $43.4 \pm 1.9 \mathrm{~mm}$ SCL and $18.2 \pm 1.9 \mathrm{~g} \mathrm{BM}(\mathrm{n}=$ 325). These hatchlings were different in SCL and mass from each group of post-hatchlings we captured offshore (Fig. 2; ANOVA, Tukey's HSD tests, $\mathrm{p}<0.05)$. The 9 post-hatchling green turtles captured averaged $54.4 \pm 1.0 \mathrm{~mm}$ SCL and $26.1 \pm 0.8 \mathrm{~g} \mathrm{BM}$.

\section{Surface-pelagic juveniles captured}

We captured 90 juvenile turtles of 4 species. The range of body mass among all species was from 420 to $3100 \mathrm{~g}$. Hawksbills $(\mathrm{n}=6)$ averaged $206 \pm 44 \mathrm{~mm}$ SCL and $1188 \pm 516 \mathrm{~g}$ BM. Two loggerheads were captured, one of $189 \mathrm{~mm}$ SCL and $1100 \mathrm{~g} \mathrm{BM}$ and the other of $217 \mathrm{~mm}$ SCL and $1600 \mathrm{~g}$ BM. Green turtles (Fig. 3; n = 44) averaged $206 \pm 22 \mathrm{~mm}$ SCL and 1248 $\pm 381 \mathrm{~g}$ BM. Kemp's ridleys (Fig. $4 ; \mathrm{n}=38$ ) averaged $233 \pm 26 \mathrm{~mm}$ SCL and $1969 \pm 702 \mathrm{~g} \mathrm{BM}$.

\section{Habitat description, turtle behavior, and use of habitat}

The consolidated patches of floating material we searched were dominated by pelagic Sargassum species but also contained woody material, seagrass, and synthetic debris. The majority of patches we surveyed (96\%) were recorded as being linear; this included contiguous, meandering lines of floating material, scattered patches that could be followed along a linear path, or parallel windrows. These parallel windrows were typically numerous, short, and distributed along a linear path. The remaining patches were scattered, with no linear pattern discernible from the search vessel.

To detect remotely observable sea-surface features that could serve as a proxy for surface pelagic habi-

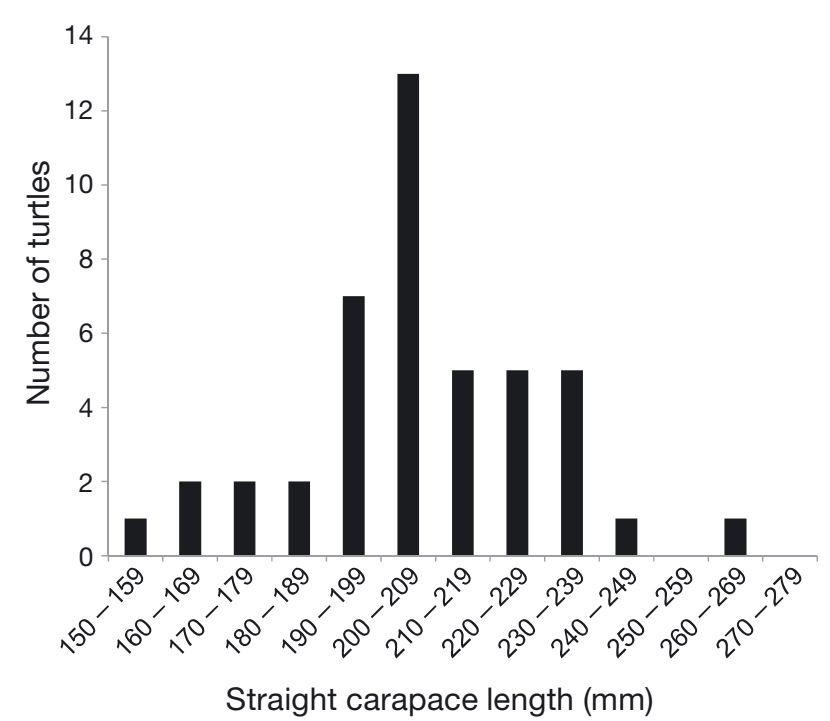

Fig. 3. Chelonia mydas. Size frequencies of 44 surfacepelagic juvenile green turtles captured from the Sargassumdominated surface-pelagic drift community off Florida

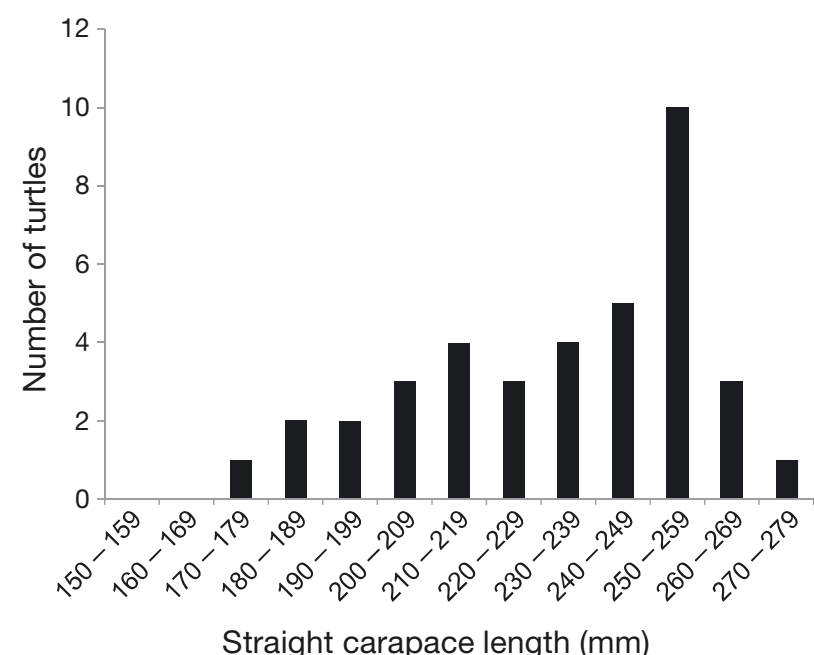

Fig. 4. Lepidochelys kempii. Size frequencies of 38 surfacepelagic juvenile Kemp's ridleys captured from the Sargassum-dominated surface-pelagic drift community off Florida 


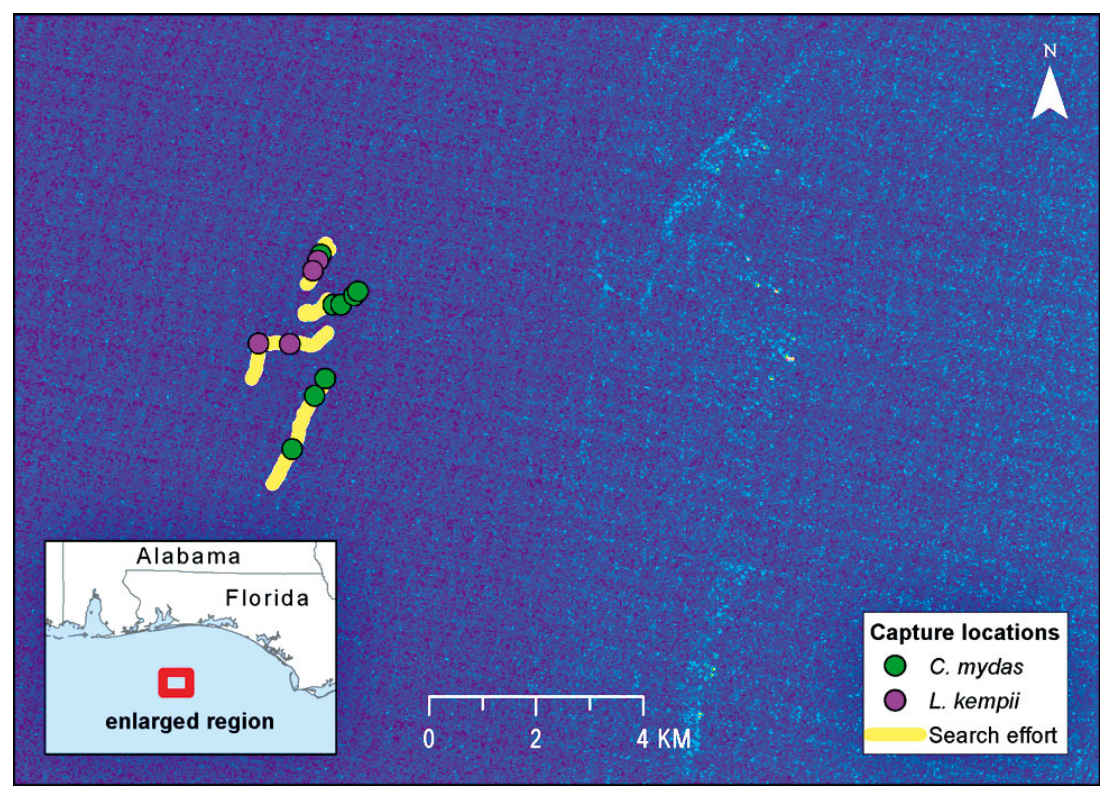

Fig. 5. Chelonia mydas, Lepidochelys kempii. Search transects (15 segment legs, yellow lines) and surface-pelagic juvenile turtle observations (8 green turtles, 4 Kemp's ridleys, green and purple dots, respectively) from 5 June 2011. Turtle locations are plotted relative to Sargassum-dominated drift habitat observed using the floating alga index (Hu 2009) applied to $30 \mathrm{~m}$ resolution Landsat-5 imagery (collected on 6 June 2011). Sargassum lines are visible as streaks to the right of the turtle points. Spatial offset was due to $1 \mathrm{~d}$ of drift during the time shift between transects and imagery

tat, we searched available satellite imagery collected at vessel-sampled locations as close in time to our sampling trips as possible. On Atlantic sampling trips, search transects during which turtles were observed were typically near the western wall of the Gulf Stream and its associated frontal boundaries. However, the positions of habitat observed during successful eastern Gulf of Mexico transects were only occasionally explained well by remotely observable SST fronts or chlorophyll concentration gradients. Where remote sensing observations were possible, these gradients were also seen to be traced along their length by pelagic Sargassum. For example, in one case a line of Sargassum and observations of 12 juvenile turtles coincided with a front described by SST (Fig. 5). We observed drifting Sargassum in Landsat imagery collected the following day, coinciding with this front.

We observed the behavior and habitat association of 919 post-hatchling and juvenile turtles encountered during transects through patches of consolidated floating material (target areas) and for 53 turtles encountered between or en route to these patches (nontarget areas). The predominant behavior and relation to floating objects recorded for turtles in target areas $(\mathrm{n}=919)$ were inactive at the surface and within $1 \mathrm{~m}$ of the nearest object $(58 \%$ of all turtles; Table 2). Only $8 \%$ of turtles were farther than $1 \mathrm{~m}$ from the closest object, and only $6 \%$ of turtles were not at the surface (not floating partially above water). The predominant object nearest to turtles in target areas was pelagic Sargassum $(89 \%)$, followed by seagrass species $(6 \%)$ and various other objects including wood, plastics, and other turtles $(5 \%)$.

Many fewer turtles were observed during searches in non-target areas $(n=53)$ than in target areas $(n=919)$. Although the turtles from non-target areas were not observed where floating material defined the search trackline, their behavior and association with floating objects was similar to that observed for the group of turtles observed in target areas, where floating material defined our search locations. Turtles in non-target areas were most commonly inactive at the surface and within $1 \mathrm{~m}$ of the nearest object ( $45 \%$ of all turtles). Only $21 \%$ of turtles were farther than $1 \mathrm{~m}$ from the closest object, which was predominantly pelagic Sargassum (78\%), followed by plastics $(7 \%)$, and various other objects including seagrasses, wood, and other turtles $(5 \%)$. Only 1 of 53 turtles observed in non-target areas was so distant (greater than approximately $100 \mathrm{~m}$ ) from the nearest floating object that no object could be identified.

\section{Dive profiles and horizontal movement}

We tracked 4 juvenile Kemp's ridleys carrying AST-05 data recorders and were able to recapture 3 of them, providing a full complement of dive data. We identified these turtles by their capture dates in 2008: 1 July, 20 July, and 30 July (Table 3). All 4 turtles moved along circuitous paths in the general direction of geostrophic currents, the speeds of which were $<1 \mathrm{~km} \mathrm{~h}^{-1}$. Distance between capture/release and retrieval locations ranged from 3 to $18 \mathrm{~km}$ (18.5 to $23.1 \mathrm{~h}$ elapsed).

Dive-profile data from retrieved data recorders showed that the turtles spent the bulk of time at or near the surface (Fig. 6, Table 3). The deepest dives 


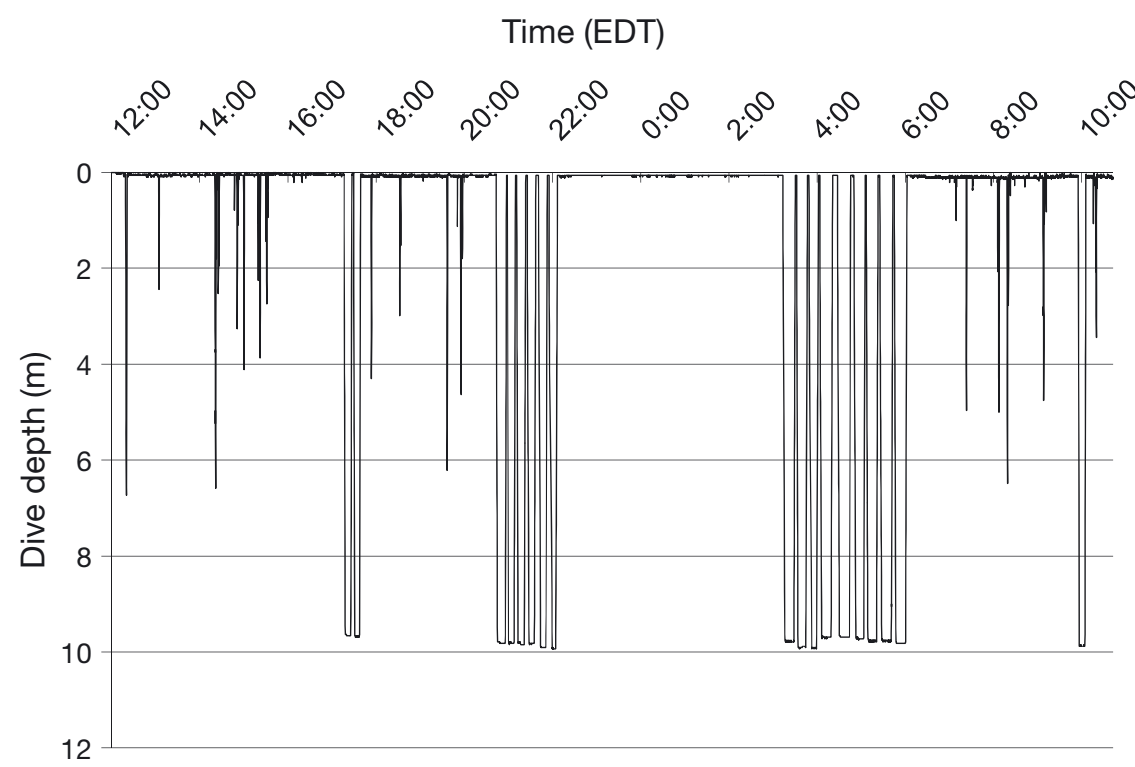

Fig. 6. Lepidochelys kempii. An example dive profile for a juvenile Kemp's ridley tracked for $22.6 \mathrm{~h}$ beginning 30 July 2008. The turtle was fitted with a depth recorder following its initial capture and release in the Gulf of Mexico, approximately 43 nautical miles west-southwest of Marco Island, Florida. Average water depth was $33 \mathrm{~m}$. During the tracking period, sunset was at 20:17 h and sunrise was at 06:54 h Eastern Daylight Time (EDT). The depth recorder logged depth at $6 \mathrm{~s}$ intervals. The turtle made 18 dives with a flatbottomed profile, each to approximately $10 \mathrm{~m}$ extended to no more than $30 \%$ of the total water column, with turtles diving to a specific depth and remaining there until their ascent. These flatbottomed dives were the longest in duration, ranging from 10 to $18 \mathrm{~min}$, and most occurred at night. The depths of these flat-bottomed dives corresponded with the depth of a sonic scattering layer recorded by the tracking vessel's sonar chart plotter. Temperature data from the recorders indicated that the deeper dives bottomed out near the thermocline.

Each of the 3 turtles providing dive data showed diurnal differences in diving behavior. During the day, turtles spent more time within $1 \mathrm{~m}$ of the surface and made more dives, which were on average shallower and shorter in duration than nocturnal dives (Table 3 ; $t$-tests, $\mathrm{p}<0.001$ ). Centered near midnight, each turtle showed a 4 to $7 \mathrm{~h}$ period of quiescence.

Table 2. Caretta caretta, Chelonia mydas, Lepidochelys kempii, Eretmochelys imbricata. Behavior of 919 post-hatchling and juvenile sea turtles observed during transects through consolidated floating material (target areas; see 'Materials and methods - Search effort, captures, and turtle data collected'). Table represents the fraction (\%) of loggerheads, green turtles, Kemp's ridleys, or hawksbills exhibiting the categorized behaviors (defined in the section cited above) and association with floating objects. Associated objects were predominantly pelagic Sargassum (89\%), followed by seagrass species (6\%), and other objects including wood, plastics, and other turtles (5\%)

\begin{tabular}{|c|c|c|c|c|c|c|c|c|c|c|c|c|}
\hline \multirow[t]{3}{*}{ Behavior } & \multicolumn{12}{|c|}{ Distance $(\mathrm{m})$ from nearest floating object by species - } \\
\hline & \multicolumn{3}{|c|}{ Loggerhead $(n=780)$} & \multicolumn{3}{|c|}{ Green turtle $(\mathrm{n}=81)$} & \multicolumn{3}{|c|}{ Hawksbill $(\mathrm{n}=3)$} & \multicolumn{3}{|c|}{ Kemp's ridley $(\mathrm{n}=55)$} \\
\hline & 0 & $0-1$ & $>1$ & 0 & $0-1$ & $>1$ & 0 & $0-1$ & $>1$ & 0 & $0-1$ & $>1$ \\
\hline Inactive & 38 & 22 & 4 & 30 & 4 & 1 & 33 & 33 & 0 & 44 & 12 & 0 \\
\hline Breath & 5 & 6 & 2 & 7 & 6 & 2 & 0 & 0 & 0 & 2 & 2 & 2 \\
\hline Slow swim & 5 & 10 & 4 & 4 & 14 & 4 & 0 & 0 & 0 & 2 & 13 & 2 \\
\hline Subsurface swim & 0 & 1 & 2 & 2 & 11 & 0 & 0 & 0 & 0 & 0 & 2 & 0 \\
\hline Front flipper movement & 1 & 0 & 0 & 15 & 0 & 0 & 33 & 0 & 0 & 10 & 9 & 0 \\
\hline
\end{tabular}

Table 3. Lepidochelys kempii. Surface time, dive frequency, dive depth, and dive duration for 3 juvenile Kemp's ridleys (1.7 to $2.1 \mathrm{~kg}$ ) tracked in the eastern Gulf of Mexico off Florida, USA. Specific tracking locations for turtles (identified by date, 2008) were $81 \mathrm{~km}$ SW of Apalachicola Bay (1 July), $120 \mathrm{~km}$ SW from Pensacola Bay (20 July), and $80 \mathrm{~km}$ W-SW from Collier Bay (30 July). Water depths ranged from 33 to $56 \mathrm{~m}$. Day and night periods were determined by local sunset and sunrise

\begin{tabular}{|c|c|c|c|c|c|c|c|c|}
\hline \multirow[t]{2}{*}{$\begin{array}{l}\text { Turtle } \\
\text { date }\end{array}$} & \multicolumn{2}{|c|}{$\begin{array}{c}\text { Percent time spent } \\
\text { at }<1 \mathrm{~m}\end{array}$} & \multicolumn{2}{|c|}{$\begin{array}{l}\text { Number of dives } \\
>1 \mathrm{~m}\end{array}$} & \multicolumn{2}{|c|}{$\begin{array}{c}\text { Dive depth } \\
(\text { mean } \pm \text { SD, m) }\end{array}$} & \multicolumn{2}{|c|}{$\begin{array}{c}\text { Dive duration } \\
\text { (mean } \pm \mathrm{SD}, \mathrm{min})\end{array}$} \\
\hline & Day & Night & Day & Night & Day & Night & Day & Night \\
\hline 1 July & 99.1 & 99.2 & 7 & 1 & $3.2 \pm 2.6$ & 6.3 & $1.0 \pm 1.1$ & 4.7 \\
\hline 20 July & 97.9 & 95.6 & 5 & 4 & $1.7 \pm 1.0$ & $12.8 \pm 7.7$ & $0.3 \pm 0.4$ & $6.7 \pm 5.5$ \\
\hline 30 July & 93.0 & 66.3 & 34 & 16 & $3.7 \pm 2.6$ & $9.8 \pm 0.1$ & $1.5 \pm 2.6$ & $14.2 \pm 2.5$ \\
\hline
\end{tabular}




\section{Diet composition}

We measured diet by sampling lavaged esophageal contents or by collecting fecal material from 42 surface-pelagic juvenile turtles ( 0.75 to $3.05 \mathrm{~kg}$ ). We grouped items identified in samples within 34 subgroupings divided between general categories (Table S1 in the supplement at www.int-res.com/ articles/suppl/m463p001_supp.pdf). Among turtles sampled by lavage or fecal collection, marine animal material was most frequent, followed by marine plants (mostly pelagic Sargassum), synthetic material (mostly plastics), unknown plants, terrestrial plants (mostly wood), terrestrial animals (insects), and minerals (mostly pumice).

Although we identified more forage items in lavage samples than in fecal samples, both sample methods showed broad overlap between the diet items chosen by the 2 best represented species, the green turtle and Kemp's ridley (Table S1 in the supplement). The most common identifiable marine animal group included hydroid species common within the pelagic Sargassum community. Other specific Sargassum community associates in either lavage or fecal samples included the anthozoan Anemonea sargassensis, the gastropods Scyllaea pelagica and Litiopa melanostoma, the swimming crab Portunus sayi, and the bryozoan Membranipora sp. Sargassum fragments represented in lavage samples typically bore encrusting hydroids, colonies of Membranipora sp., and the tubes of Spirorbis sp. (a serpulid polychaete). Stephanolepis hispida, a filefish common in pelagic Sargassum, was found in a lavage sample from a green turtle and in the mouth of a Kemp's ridley that did not undergo lavage.

Mean percentage dry mass of animal material was greater in both lavage and fecal samples of Kemp's ridleys than in those of green turtles (Table 4). For

Table 4. Chelonia mydas, Lepidochelys kempii. Percentage dry mass (mean $\pm \mathrm{SD}$ ) of animal, plant, synthetic, and mineral material identified in esophageal lavage and fecal samples from surface-pelagic juvenile green turtles $(n=18)$ and Kemp's ridleys $(\mathrm{n}=20)$ captured from pelagic Sargassum habitat off Florida, USA

\begin{tabular}{|lccccc|}
\hline & \multicolumn{2}{c}{ Green turtle } & \multicolumn{2}{c|}{ Kemp's ridley } \\
& $\begin{array}{l}\text { Lavage } \\
(\mathrm{n}=16)\end{array}$ & $\begin{array}{c}\text { Fecal } \\
(\mathrm{n}=14)\end{array}$ & $\begin{array}{c}\text { Lavage } \\
(\mathrm{n}=13)\end{array}$ & $\begin{array}{c}\text { Fecal } \\
(\mathrm{n}=19)\end{array}$ \\
\hline Animal & $51.4 \pm 38.5$ & $21.5 \pm 25.6$ & $90.3 \pm 27.8$ & $62.5 \pm 37.7$ \\
Plant & $36.1 \pm 35.7$ & $56.3 \pm 37.1$ & $2.1 \pm 6.0$ & $26.3 \pm 30.2$ \\
Synthetic & $12.5 \pm 29.5$ & $20.7 \pm 32.5$ & $7.5 \pm 27.8$ & $11.2 \pm 21.1$ \\
Mineral & 0 & $1.5 \pm 5.5$ & 0 & $<0.1 \pm 0.1$ \\
\hline
\end{tabular}

green turtles, mean percentage dry mass of animal material was greatest in lavage samples, but, in fecal samples, mean percentage dry mass of plant material was greatest. Plastics made up the bulk of synthetic material in samples and averaged $13 \%$ of dry mass for both species and both sampling methods (Table 4).

\section{Density of turtles within surveyed habitat}

From 2005 to 2011, we recorded distance from transect for sea turtles observed in target areas (Sargassum community habitat, $797 \mathrm{~km}$ ) and non-target areas (open water, $14182 \mathrm{~km}$ ) surveyed along vessel course lines. Turtles observed included 342 posthatchlings and 129 juveniles observed in target areas and 1 post-hatchling and 39 juveniles observed in non-target areas. For turtles within target areas, because of similar sizes and behaviors within each life-stage group, we pooled species within these groups for our analysis of the probability density function of observed distances (Table 5). However, we divided analyses between observations in the Gulf of Mexico and Atlantic Ocean, excluding juveniles observed in the Atlantic, for which the sample size $(\mathrm{n}=5)$ was small. All turtles observed in nontarget areas were juveniles from the Gulf of Mexico except for a single post-hatchling from the Gulf, which was pooled with the juvenile data.

To achieve the best model fits, we analyzed target area distance data truncated to $100 \mathrm{~m}$ for juveniles, $50 \mathrm{~m}$ for Gulf post-hatchlings, and $25 \mathrm{~m}$ for Atlantic post-hatchlings (truncations recommended by Distance 6.0). For turtles within non-target areas, we analyzed distance data truncated to $60 \mathrm{~m}$ for all turtle observations.

Effective strip width (ESW) estimates the half width outside of which the number of detected turtles equals the number missed inside the ESW. Estimates of ESW for target areas were highest for transects in the Gulf of Mexico, which had a relatively low number of post-hatchling observations and a relatively high number of juvenile observations (Table 5). These Gulf transects were more commonly recorded as being through wide and indefinite Sargassum lines, compared with Atlantic transects, which were typically along lines adjacent to the Gulf Stream front. The ESW estimate for non-target areas, which were areas of open water without consolidated Sargassum, was higher than any of the estimates for target areas (Table 5). Using the estimates for $f(0)$ and assuming $g(0)=1$, we calculated densities of each turtle life 
Table 5. Caretta caretta, Chelonia mydas, Eretmochelys imbricata, and Lepidochelys kempii. Data and estimates applied to surface-pelagic sea turtle observations made during search transects through pelagic Sargassum (target areas) and en route to patches of pelagic Sargassum (non-target areas) in the Atlantic Ocean and Gulf of Mexico off Florida. Offshore trips were made from May to September between 2005 and 2011. Estimates include $f(0)$ : the value of the probability density function of observed perpendicular distances from the transect lines, evaluated for distance 0; ESW: effective strip width estimating the half width outside of which the number of detected turtles equals the number missed inside the ESW; n/L: number of observed turtles per kilometer of linear transect. The number of juvenile observations in the Atlantic was not sufficient for an analysis. Each search day was counted as a single transect search. Only transects conducted during the regional sea turtle hatching season (July to October) counted toward transect length for the post-hatchling estimates

\begin{tabular}{|c|c|c|c|c|c|}
\hline & \multicolumn{4}{|c|}{ - Target areas } & \multirow{3}{*}{$\begin{array}{c}\text { Non-target areas } \\
\text { (Gulf \& Atlantic) } \\
\text { Post-hatchlings } \\
\text { and juveniles }\end{array}$} \\
\hline & \multicolumn{2}{|c|}{ Gulf of Mexico } & \multicolumn{2}{|c|}{ Atlantic Ocean } & \\
\hline & Post-hatchlings & Juveniles & Post-hatchlings & Juveniles & \\
\hline Total transect length $(\mathrm{km})$ & 539 & 650 & 147 & 147 & 14182 \\
\hline No. of transects & 37 & 45 & 10 & 10 & 60 \\
\hline Observed turtles & 31 & 129 & 308 & 5 & 40 \\
\hline$f(0)(95 \% \mathrm{CI})$ & $0.077(0.063-0.094)$ & $0.069(0.061-0.078)$ & $0.266(0.251-0.283)$ & - & $0.049(0.037-0.065)$ \\
\hline ESW (m) $(95 \%$ CI) & $13.0(10.6-15.9)$ & $14.6(12.9-16.5)$ & $3.8(3.5-4.0)$ & - & $20.5(15.4-27.2)$ \\
\hline n/L (no. km $\left.{ }^{-1}\right)(95 \%$ CI $)$ & $0.063(0.023-0.177)$ & $0.198(0.139-0.284)$ & $2.09(0.67-6.55)$ & 0.03 & $0.0028(0.00175-0.0045)$ \\
\hline
\end{tabular}

Table 6. Caretta caretta, Chelonia mydas, Eretmochelys imbricata, and Lepidochelys kempii. Relative density of turtles $\left(D\right.$, turtles $\left.\mathrm{km}^{-2}\right)$ and $95 \%$ confidence intervals (CIs) for turtles in pelagic Sargassum habitat (target areas) in the Gulf of Mexico and Atlantic Ocean off Florida. Estimates are from detectability functions modeled using observed turtles' perpendicular distances from the transect (see 'Materials and methods'), measured on search trips made from May to September between 2005 and 2011. The percentage by species shows proportions within each life stage by area

\begin{tabular}{|lccccc|}
\hline & \multicolumn{3}{c}{ Gulf of Mexico- } & & \multicolumn{2}{c|}{ Atlantic Ocean- } \\
\cline { 2 - 5 } & $\begin{array}{c}\text { Post-hatchlings } \\
(\mathrm{n}=31)\end{array}$ & $\begin{array}{c}\text { Juveniles } \\
(\mathrm{n}=129)\end{array}$ & & $\begin{array}{c}\text { Post-hatchlings } \\
(\mathrm{n}=308)\end{array}$ & $\begin{array}{c}\text { Juveniles } \\
(\mathrm{n}=5)\end{array}$ \\
\hline D all species (95\% CI) & $2.4(0.85-6.9)$ & 7.0 & $(4.8-10.2)$ & $279(89.1-873)$ & No estimate \\
Loggerhead (\%) & 100 & 2.33 & 95.8 & 0 \\
Green turtle (\%) & 0 & 51.9 & & 4.22 & 80 \\
Kemp's ridley (\%) & 0 & 44.2 & & 0 & 0 \\
Hawksbill (\%) & 0 & 1.55 & 0 & 20 \\
\hline
\end{tabular}

stage for Sargassum community habitat within Gulf and Atlantic study areas (Table 6). Because the search vessel speed differed between target and non-target areas, we compare turtle density estimates between these 2 groups cautiously. For nontarget areas, the density estimate was 0.069 turtles $\mathrm{km}^{-2}$ $(95 \% \mathrm{CI}=0.040$ to 0.119$)$, approximately 2 orders of magnitude lower than the estimates for Gulf juveniles within target areas (Table 6).

Table 7. Caretta caretta, Lepidochelys kempii, Chelonia mydas, and Eretmochelys imbricata. Straight carapace length ranges $(\mathrm{mm})$ for life stages of 4 species of sea turtles captured from habitat in the North Atlantic Ocean and Gulf of Mexico. Turtles within pelagic Sargassum habitat are from the present study. Turtles from other surface-pelagic habitat are from the eastern Atlantic near the Azores and Madeira. Turtles from 'other surface-pelagic' habitat are from the eastern Atlantic near the Azores and Madeira. Turtles from 'neritic/benthic' habitats (including some likely adults) are from coastal waters of the eastern Gulf of Mexico; northeastern Gulf, Florida Bay, and the Florida Keys

\begin{tabular}{|c|c|c|c|c|c|c|c|c|}
\hline \multirow[t]{3}{*}{ Species } & \multicolumn{4}{|c|}{ Pelagic Sargassum community } & \multirow{2}{*}{\multicolumn{2}{|c|}{$\begin{array}{c}\text { Other surface-pelagic } \\
\text { Juvenile }\end{array}$}} & \multirow{2}{*}{\multicolumn{2}{|c|}{$\begin{array}{c}\text { Neritic/benthic } \\
\text { Immature and adult }\end{array}$}} \\
\hline & \multicolumn{2}{|c|}{ Post-hatchling } & \multicolumn{2}{|c|}{ Juvenile } & & & & \\
\hline & Range & $\mathrm{n}$ & Range & $\mathrm{n}$ & Range & $\mathrm{n}$ & Range & $\mathrm{n}$ \\
\hline Loggerhead & $39-78$ & 1369 & $189-217$ & 2 & $94-777^{a}$ & 731 & $317-987^{\mathrm{b}, \mathrm{c}, \mathrm{d}, \mathrm{e}}$ & 1136 \\
\hline Kemp's ridley & - & & $175-276$ & 38 & - & & $207-652^{\mathrm{b}, \mathrm{c}, \mathrm{d}, \mathrm{e}}$ & 634 \\
\hline Green turtle & $53-56$ & 10 & $150-263$ & 44 & - & & $260-1090^{b, c, d, e}$ & 413 \\
\hline Hawksbill & - & & $134-248$ & 6 & - & & $214-690^{\mathrm{e}}$ & 79 \\
\hline \multicolumn{9}{|c|}{$\begin{array}{l}{ }^{a} \text { Turtles from the eastern Atlantic near the Azores and Madeira (Bolten et al. 1993) with SCL converted from curved cara- } \\
\text { pace length (CCL) using CCL = } 1.388+(1.053) \text { (SCL), after Bjorndal et al. }(2000) ;{ }^{b} \text { turtles from coastal waters of the eastern } \\
\text { Gulf of Mexico (Schmid 1998, Witzell \& Schmid 2004, Barichivich 2006); }{ }^{c} \text { turtles from the northeastern Gulf (McMichael et } \\
\text { al. 2006); }{ }^{d} \text { turtles from Florida Bay (Schroeder et al. 1998), }{ }^{e} \text { turtles from the Florida Keys (Bresette et al. 2010, Inwater } \\
\text { Research Group unpubl. data) }\end{array}$} \\
\hline
\end{tabular}




\section{DISCUSSION}

\section{Filling the information gap on lost-year turtles}

The sea turtles on which we report represent a life stage between hatchlings, which are well known from nesting beaches, and benthic-foraging immature turtles, well known from coastal and nearshore studies (Table 7).

\section{Loggerhead sea turtles}

Because loggerheads nest in large numbers on Florida beaches (Witherington et al. 2009), it is not surprising that this species was well represented in observations of post-hatchlings on transects off Florida. The loggerhead post-hatchlings we captured were slightly larger than hatchlings measured at nearby nesting beaches (Fig. 2), indicating that the post-hatchlings had begun to feed and grow following their offshore recruitment. This growth was most pronounced in the group of loggerhead post-hatchlings captured farthest from nesting beaches (Fig. 1). Post-hatchlings from locations farther than $80 \mathrm{~km}$ from shore (Atlantic off St. Augustine; all Gulf locations) were approximately $40 \%$ larger (by mass) than post-hatchlings captured closer to nesting beaches. We do not know the precise age of these larger posthatchlings, but even the largest turtles captured (73 g, 4 times hatchling mass) were unlikely to have been $>2$ mo old given their capture date relative to first hatching on regional beaches (Witherington et al. 2006). Carapace lengths of these larger posthatchlings (Fig. 2) were in keeping with the approximate growth rate of $10 \mathrm{~mm} \mathrm{mo}^{-1}$ estimated by Bjorndal et al. (2000) for young-of-the-year.

Bolten (2003a) categorized loggerhead post-hatchlings as in transition between neritic and oceanic habitats following their hatchling swim-frenzy stage (the approximately $1 \mathrm{~d}$ period of constant swimming after leaving the natal beach; Wyneken \& Salmon 1992). In keeping with this categorization, we observed loggerhead post-hatchlings in both deep neritic and oceanic waters. Because water depths were $>30 \mathrm{~m}$, the vast majority of our capture locations would not have afforded post-hatchlings access to benthic foraging opportunities, in light of their observed relatively shallow $(<4 \mathrm{~m})$ diving behavior (Wyneken 1997, authors' pers. obs.). Irrespective of water depth, we found larger (presumably older) post-hatchlings farther from the coastline (Fig. 2), but we did not observe evidence that the neritic/oceanic boundary coincided with a biological shift for young loggerheads. Indeed, many of the larger post-hatchlings from the Gulf of Mexico were captured from surface-pelagic neritic waters that they had likely inhabited for weeks or months. In contrast to this sluggish dispersal, loggerheads of similar size are also found during late August in surface-pelagic oceanic waters as distant as the Grand Banks off Newfoundland (K. Mansfield pers. comm.), a $2500 \mathrm{~km}$ Gulf Stream drift from the principal nesting beaches of the southeastern USA.

The 5 juvenile loggerheads we observed were at least $1 \mathrm{yr}$ old, if we assume growth rates similar to those in captive turtles (Higgins 2003). Juvenile sizes were at the lower end of size distributions developed for loggerheads in the eastern Atlantic (Bolten et al. 1993; present study Table 7).

\section{Kemp's ridleys}

The sizes of Kemp's ridleys we observed suggest that the turtles were an incomplete sample of the life stage. The size distribution was unimodal (excluding a minor submode), with a lower tail including turtles no smaller than $170 \mathrm{~mm}$ SCL (Fig. 4). This leaves a gap between observed turtles and the hatchling size of $44 \mathrm{~mm}$ (Marquez 1994). The principal source of hatchlings for this species is the stretch of nesting beach at Tamaulipas, Mexico $\left(23.28^{\circ} \mathrm{N}, 97.58^{\circ} \mathrm{W}\right)$, in the western Gulf (Plotkin 2007). We hypothesize that the gap in surface-pelagic Kemp's ridley sizes is the result of the spatial (eastern Gulf of Mexico) and temporal (May-September) characteristics of our sampling effort. That is, smaller (younger) Kemp's ridleys west of our study area were not included in our sample.

The unimodal size-class distribution of juvenile Kemp's ridleys (Fig. 4) gave little evidence that multiple year classes were represented. Because our sampling period was concurrent with annual hatchling production (Marquez 1994), we conclude that the ridleys we sampled were at least $1 \mathrm{yr}$ old. Given the somatic growth potential in captive turtles (Higgins 2003) and growth rates modeled for wild turtles (Chaloupka \& Zug 1997), we estimate that the Kemp's ridleys we observed were either 1 or 2 yr old. Interestingly, the modal size of these ridleys $(250 \mathrm{~mm})$ was skewed negatively (favoring larger turtles) and was similar to the lower size observed within nearby coastal-neritic habitats (Schmid 1998, Witzell \& Schmid 2004, Barichivich 2006, McMichael et al. 2006, Seney 2008). Because of their size, and because most of the 
turtles we observed were not within currents that could immediately transport them out of the Gulf of Mexico, we hypothesize that the turtles were on the cusp of recruitment into coastal habitats of the northern and eastern Gulf of Mexico.

The narrowness of the class distribution for Kemp's ridleys that we observed in the eastern Gulf of Mexico suggests a remarkably precise fit to the dispersal scenarios proposed by Collard \& Ogren (1990). In their treatment of how young Kemp's ridleys would behave as drifters in Gulf current systems, they hypothesized gradual transport from west to east, ending when most young Kemp's ridleys recruit into estuarine and nearshore habitats of the northern and eastern Gulf. Our data suggest that an important recruitment pulse, marking the end of the surfacepelagic stage and the beginning of the neritic, benthic-foraging stage, takes place primarily in the northern and eastern Gulf. Given that no other opensea habitat has been described for this species in any region, and hypothesizing the link between surfacepelagic and benthic habitats in the area we sampled, we propose that the open waters of the northern and eastern Gulf of Mexico are of unique importance to Kemp's ridleys.

\section{Green turtles}

Carr \& Meylan's (1980) observations of 3 posthatchlings in pelagic Sargassum off Panama has provided the most widely cited direct evidence for an open-sea stage in young green turtles, other than the negative evidence that this stage was unknown from more familiar coastal habitats. Following this observation, Carr (1987) published several additional records of small green turtles in Sargassum or otherwise under circumstances that suggested the turtles had occupied pelagic habitat. Most recently, substantial inference of the surface-pelagic life stage has come from the gut contents of dead post-hatchlings found stranded or in the stomachs of commercially caught fishes (Boyle \& Limpus 2008), from gut contents of green turtles caught by commercial fisheries in the Pacific (Parker et al. 2011), and from stableisotope data from the scutes of larger neritic green turtles (Reich et al. 2007). Our data add in situ measurement of behavior, diet, habitat use, and relative abundance for this open-sea life stage.

As for the juvenile Kemp's ridleys we recorded, our size distribution of green turtles suggests an incomplete sample of surface-pelagic individuals. But unlike the Kemp's ridleys we captured, 2 discrete life stages were represented in the green turtles - posthatchling and surface-pelagic juvenile. The 9 posthatchling green turtles we captured (mean $=54 \pm$ $1.0 \mathrm{~mm}$ SCL) were slightly larger than, but only 1 standard deviation different from, green turtle hatchlings measured at the closest nesting beach (Brevard County, Florida; mean $=52 \pm 1.6 \mathrm{~mm} \mathrm{SCL}$ ) by Ehrhart (1980), suggesting that they had only recently recruited to surface pelagic habitat. These green turtles represented $1 \%$ of all observations of post-hatchlings (14/1367). The proportion is smaller than expected given that green turtles accounted for $7.5 \%$ of the nesting on the closest Florida beaches from 1992 to 2009 (Florida Fish and Wildlife Conservation Commission, Index Nesting Beach Survey data). Witherington (2002) noted no green turtle observations among 293 loggerhead post-hatchlings recorded from the western Gulf Stream and attributed this to species differences in habitat use or to green turtle post-hatchlings eluding observers. In the present study, our observations of post-hatchling green turtles affirm the validity of both explanations. Although all 14 post-hatchlings we recorded were within $1 \mathrm{~m}$ of floating Sargassum, the turtles were all in states of activity, which is in contrast to the behavior of most loggerheads. The green turtles were actively manipulating Sargassum (50\%), swimming subsurface $(29 \%$, possibly in avoidance of the search vessel), or in a breath/dogpaddle (21\%) type of behavior. We hypothesize that green turtles may be less visible during searches due to subsurface swimming and avoidance.

The juvenile green turtles we captured had a relatively symmetrical, unimodal size distribution (Fig. 3). There was a gap of $90 \mathrm{~mm}$ (60-150 mm SCL) between these juvenile turtles and the post-hatchling green turtles we recorded. As with surface-pelagic Kemp's ridleys, the spatial distribution of green turtles in this life stage may shift with the seasons and with juvenile development. A genetic analysis that would identify nesting beaches for these green turtles is under way.

The narrow, unimodal size distribution for juvenile green turtles did not reveal multiple age classes. Given somatic growth modeled from carapace length and skeletochronology (Goshe et al. 2010), the juvenile green turtles we captured were 1 to $2 \mathrm{yr}$ old. Unlike the juvenile ridleys we captured, these green turtles showed almost no size-class overlap with nearby benthic foraging populations (Table 7). We hypothesize that juvenile green turtles larger than the ones we report on occupy surface-pelagic habitats within as yet unsampled areas. However, the gap 
we identify also may be the result of seasonal sampling bias. That is, growth of juveniles during the fall and winter, a period unrepresented in our sample, could substantially reduce the size gap between deepwater and shallow-water green turtles.

Hawksbills

In addition to the 6 hawksbills captured during this study, several accounts of shore strandings have associated juvenile hawksbills with pelagic Sargassum (Carr 1987, Meylan \& Redlow 2006). One study of first-day hatchling dispersal reported interaction between Sargassum and hawksbills (Hasbún 2002).

The gap between hatchlings on nesting beaches and the smallest juvenile turtles we captured spans approximately $90 \mathrm{~mm}$ of growth. At the upper range of our 6 hawksbills, carapace lengths overlap with those of turtles from the Florida Keys, a foraging location likely to hold the closest population of juveniles in shallow coastal waters (Table 7). Thus, it seems likely that some of the hawksbills we describe are of an assemblage on the cusp of recruitment into neritic/benthic habitats.

In a group of 42 juvenile hawksbills ranging from 52 to $368 \mathrm{~mm}$ SCL stranded on Texas beaches, Bowen et al. (2007) estimated a genetic contribution of $93 \%$ from nesting beaches at Yucatan, Mexico. The Yucatan rookery is the largest in the region (Garduño-Andrade 1999) and produces hatchlings that are likely to be carried north into the Gulf of Mexico by the current through the Yucatan Channel (Blumenthal et al. 2009). Strandings of small juvenile hawksbills are also common in Florida, where turtles ranging from 50 to $249 \mathrm{~mm}$ were the most numerous size class in a group of 356 (Meylan \& Redlow 2006). It is likely that these stranded hawksbills and the hawksbills we captured have similar origins.

\section{Terminology}

We propose the term 'surface-pelagic' for the developmental stage of young sea turtles described in this study. This life stage includes days-old posthatchlings that have just ended their period of active dispersal (frenzied swimming) from their nesting beach and includes slightly older/larger juveniles that forage almost exclusively at the surface or in the water column. The distribution of surface-pelagic turtles can include neritic and oceanic waters.
Other terms are commonly used to refer to the surface-pelagic life stage. These modifiers of life stage, developmental stage, or phase include lost-year (Carr et al. 1978), pelagic (Bolten et al. 1993), oceanic (Bolten 2003a), and epipelagic (Carr 1987, Meylan et al. 2011). The life stage that follows in sea turtle development is the neritic (or benthic) stage (Bolten 2003a, Meylan et al. 2011), which is defined by a shift in foraging behavior and spatial distribution.

Meylan et al. (2011) argue that the term epipelagic best describes the observed spatial distribution and behavior of young sea turtles. They point out that a pelagic distribution includes great depths unlikely to be occupied by young sea turtles, and that an oceanic distribution (waters $>200 \mathrm{~m}$ ) does not include neritic waters where young sea turtles forage. In the present study, we found no evidence that turtle behavior and vertical foraging distribution varied relative to the $200 \mathrm{~m}$ depth-contour line dividing oceanic and neritic waters.

We agree with Meylan et al. (2011) that epipelagic is a term that describes the distribution of young sea turtles more specifically than the term pelagic, in that epipelagic applies only to pelagic waters within $200 \mathrm{~m}$ of the surface. However, this includes waters much deeper than the principal zone occupied by the turtles in our study, inferred from Sargassum association, diet, and limited dive data. The epipelagic zone is also deeper than the principal distribution within the water column reported for juvenile loggerheads larger than those in this study (Bolten 2003b, Polovina et al. 2003). These studies and the present study showed that turtles spent the bulk of their time within $20 \mathrm{~m}$ of the surface, a dive pattern that is the inverse of patterns observed in larger neritic/benthic stage turtles (Hochscheid et al. 1999, Houghton et al. 2002, Seminoff et al. 2006).

Information from the present study suggests that the term 'surface-pelagic' conflicts least with the observed spatial distribution and behavior of young sea turtles. We do not suggest dispensing with the lost year term, which retains both historical context and popular use. But for technical usage, the terms pelagic, oceanic, and epipelagic may be either too broad or too narrow for the life stage they describe.

\section{Ties between sea turtles and the pelagic Sargassum community}

We conclude that post-hatchling and early-juvenile sea turtles are strongly associated with the surfacepelagic Sargassum community in the region we sam- 
pled. Our conclusion is based on the turtles' behavior, use of Sargassum habitat, and diet. Among all species and life stages we recorded, $89 \%(n=919)$ of turtles, when first observed, were within $1 \mathrm{~m}$ of floating Sargassum (Table 2). The vast majority of turtles were inactive at the surface, indicating that they were drifting within Sargassum rather than transiting through it. Of the turtles active at the surface, most were found with their front flippers or mouths actively touching or manipulating Sargassum, a behavior consistent with active foraging. These observations support hypotheses describing Sargassum habitat as a substrate for both concealment and foraging.

In a description of post-hatchling loggerheads within the Sargassum community, Witherington (2002) described the turtles as low-energy, float-and-wait foragers. The data we present here are in keeping with this description for loggerheads, as well as for surface-pelagic juvenile green turtles, Kemps' ridleys, and hawksbills. Perhaps in deviation from this pattern, each of the 14 post-hatchling green turtles we observed was in some state of activity when seen, although each was also within $1 \mathrm{~m}$ of the nearest Sargassum patch. Half of these green turtles when first observed were crawling on or within the Sargassum, indicating a less passive foraging style than that of loggerhead post-hatchlings. However, we cannot rule out observer effects prompting dives and subsurface swimming in the $29 \%$ of post-hatchling green turtles exhibiting those behaviors when first seen. Some of these turtles clearly responded to the vessel before we tried to capture them. These responses are similar to those of post-hatchling green turtles presented predation-like stimuli in captive trials (Mellgren et al. 2003), responses that make us question a comparison of resting and foraging behaviors of post-hatchling green turtles and loggerheads observed in situ.

We recorded an association with floating material, principally Sargassum, for turtles in both target areas (transects through Sargassum patches) and nontarget areas (searches en route to patches). Because of differences in search effort (e.g. vessel speed) between the 2 areas, we compare turtle densities between them cautiously. But given that apparent turtle densities were 100 times higher in targeted Sargassum patches than in open water between consolidated patches, we conclude that consolidated Sargassum patches strongly determine pelagic neonate turtle distribution. Even in areas without consolidated patches, turtles were observed to be most commonly associated with floating material, which was typically limited to widely scattered Sargassum clumps. Of 919 neonate sea turtles observed, only one, a loggerhead post-hatchling, was seen where the nearest floating object was so distant it could not be identified.

Although our sample size is small, the diving behavior we recorded for juvenile Kemp's ridleys (Fig. 6, Table 3) supports our conclusions about the behavior of surface-pelagic juveniles relative to surface material. These turtles spent the vast majority of their time at the surface and drifted with the surface currents advecting the surrounding Sargassum patches. However, the dive data also indicate that the turtles used the water column beneath the Sargassum, with the nocturnally assembled scattering layer near the thermocline (depth $<19 \mathrm{~m}$ ) standing out as particularly important.

The range of diet items we recorded also supports a strong association between surface-pelagic turtles and the Sargassum community (Table S1 in the supplement). The majority of food items were organisms known to be closely associated with the Sargassum community (described in Butler et al. 1983). These included sessile animals or meiofaunal associates of pelagic Sargassum that are seldom recorded outside this surface drift community. Remaining items included planktic organisms common near the surface such as jellies, pyrosomes, and fish eggs, and drift carrion such as insects, which we observed to be occasionally common within convergence zones. This array of ingested material is similar to that reported in stranded, 'surface-pelagic-size' loggerhead (Carr \& Meylan 1980, Carr 1987, Plotkin 1999), Kemp's ridley (Shaver 1991), green (Carr 1987), and hawksbill turtles (Carr 1987, Meylan \& Redlow 2006) in the North Atlantic and Gulf of Mexico.

Although we did not quantify density or linearity of floating material, our qualitative assessment was that density of sea turtles increased proportionally with both density and linearity of Sargassum. Turtles were most frequent where we recorded the search area to be lines of Sargassum with downwelling of buoyant material, water color change, or current ripples indicating strong convergence. Sargassum was most dense under these circumstances, even when lines were narrow due to low Sargassum biomass. But because most of our captures were made in Sargassum outside these dense convergence zones (i.e. scattered patches, weak convergences, and Langmuir windrows), we cannot conclude that these strong convergences are essential to surface-pelagic juveniles. This point runs counter to assertions that foraging habitat and hatchling orientation goals are defined principally by the boundaries of major currents like the Gulf Stream (e.g. Kraemer \& Bennett 
1981, Lohmann \& Lohmann 1996). Indeed, none of our searches in the Gulf of Mexico were at a major current boundary like those rimming the Gulf Loop Current or its offshoot mesoscale eddies. However, given the apparent extent of drift habitat within these major convergence zones (Sargassum visible by remote sensing; Gower et al. 2006, Gower \& King 2011), measuring densities of juvenile turtles there would be critical to further understanding of the distribution of this life stage.

\section{Complex trophic relationships}

The dietary analysis of turtles in situ that we present here adds to that of Witherington (2002) in describing food choices made by surface-pelagic turtles. Our analysis has strengths in that it does not rely on a biased sample of dead turtles or on turtles that came from an unknown foraging area. But a weakness of our methodology may be in our reliance on esophageal and fecal samples. Because we did not sample the entire gut, we concede that there may be bias in our detection of food items. For example, jellies were more extensively represented in esophageal lavage samples than in fecal samples (Table S1 in the supplement). However, coupling of the 2 sampling methods probably reduced bias of the combined diet analysis, which employed methods allowing the use of live animals in situ.

Because we obtained most of our samples from juvenile green turtles and Kemp's ridleys, our conclusions about diet apply principally to these species. Food items for these turtles were drawn extensively from the fauna of the pelagic Sargassum community, with other animal species including jellies and insects. This animal material composed most of the mean dry mass of diet samples, except for green turtle fecal samples, which were mostly plant material (Table 4).

The largest contributor to the plant fraction in all samples was Sargassum. Macroalgae within this genus are generally described as being unpalatable to herbivores (Hay 1986) due to the alga's leathery, heavily corticated stipes and fronds. Perhaps indicating the alga's indigestibility to sea turtles, most of the fragments we recorded from fecal samples were almost indistinguishable from fresh samples, except for their darker color. Because the Sargassum fragments in esophageal samples in this study most commonly bore sessile, epiphytic animals, we suggest that ingestion of Sargassum was largely incidental to foraging for these animals. Such incidental ingestion of pelagic Sargassum is also seen in the piscivorous dolphinfish Coryphaena hippurus (Manooch et al. 1984).

Our opportunistic observations of potential prey animals in the habitat where turtles were captured indicated that turtles commonly exploited temporarily abundant prey. In 3 cases where the jellies Aequorea spp., Porpita porpita and Pelagia noctiluca were recorded as being extraordinarily dense in the habitat searched, each of the turtles we captured from that habitat had these jellies in their esophagus. A similar spatiotemporal clustering in carrion, such as dead insects, may influence diet choices. As members of the aerial plankton, insects are likely to be concentrated by atmospheric events as well as surface currents.

Prominence of insects in the diet of young sea turtles has been reported elsewhere (Richardson \& McGillivary 1991, Witherington 2002, Boyle \& Limpus 2008, Russell et al. 2011); the diet information we report supports the hypothesis that insects are a common source of nutrition for young sea turtles. Terrestrial origins of this food source add complexity to a trophic description for surface-pelagic juvenile turtles. To further split the terrestrial habitats contributing to this animal material, we found insect species typical of both aquatic habitats (dytiscid water beetles, libellulid dragonflies) and upland communities (ants, grasshoppers, aphids). Although the ingested woody material we recorded may have been mostly indigestible, it also could have contributed items of terrestrial origin to the turtle's diet. We recorded likely marine-benthic animals in diet samples as well, including veliger larvae and the crab Achelous spinimanus, which is principally a demersal species, although we observed it as occasionally common in deepwater pelagic Sargassum. Trophic studies using stable isotopes are sure to yield valuable insight into how these surface-pelagic turtles assimilate energy and nutrients, but we suggest that care be taken in the development of isotopic baselines.

We propose that the diet of surface-pelagic turtles within the Sargassum community is that of a generalist, opportunistic, omnivore. Although their diet favors animals of the Sargassum community, their food choices are broadened by scavenging and indiscriminate feeding to include drift carrion and marginally digestible or indigestible floating items such as wood, charcoal, pumice, and synthetic debris.

We conclude that ontogenetic movement by juvenile turtles from surface-pelagic to coastal waters results in an important dietary shift from omnivory to either carnivory (loggerheads and Kemp's ridleys) or 
herbivory (green turtles). Reich et al. (2007) found evidence of such a shift revealed by carbon and nitrogen stable isotope signals in scutes from young herbivorous green turtles inhabiting Atlantic coastal waters. The stable isotope ratios across scute layers of different ages showed that the turtles had spent 3 to 5 yr as carnivores before making a rapid transition to a plant diet. Evidence from the Pacific, where pelagic Sargassum does not dominate surface waters, suggests that green turtles there also undertake a dietary shift following recruitment to shallow waters from open-sea habitats. A sample of 10 green turtles (300 to $700 \mathrm{~mm}$ SCL) incidentally caught by surfacepelagic long-lines set in the central North Pacific had guts containing mostly animal material in addition to algae and various debris (Parker et al. 2011). This is in contrast to a low rate of animal ingestion (5.6\%) in green turtles from coastal waters of the nearby Hawaiian Islands (Russell et al. 2011).

\section{Pelagic Sargassum as a transient hot spot}

The presence of floating Sargassum defined habitat that contained young sea turtles, often irrespective of other detectable surface features such as water color gradients. We found varied coincidence between remotely sensed SST or chlorophyll concentration anomalies and convergence zones containing turtles, perhaps due to the relatively coarse spatial resolution of the satellite data. For our Atlantic observations, most turtles were found in Sargassum lines oriented parallel to and within a few kilometers of the western frontal boundary of the Gulf Stream, a feature clearly visible in satellite imagery. However, in the Gulf of Mexico, patchiness of turtles and Sargassum was within areas of seemingly homogeneous surface water. From our observations in situ, these patches had scales in the tens or hundreds of meters and longevities of hours, perhaps too small and ephemeral to be observed in our set of remote-sensing data.

We hypothesize that surface-pelagic sea turtle habitat in the region we surveyed is concentrated in linear hot spots that are both transient and shortlived, attributes shared with the pelagic Sargassum drift community (Thiel \& Gutow 2005a,b). Describing the spatiotemporal patterns of this dynamic habitat on a scale relevant to sea turtle conservation will require higher resolution satellite imagery. Recently developed techniques in remote sensing ( $\mathrm{Hu}$ 2009) offer the potential of measuring this habitat with a single tracer, surface Sargassum. Regionwide measurement of pelagic Sargassum area, coupled with measured density of juvenile turtles in Sargassum, may provide helpful descriptions of sea turtle distribution. To accomplish this task, Sargassum would need to be mapped using methods capable of identifying lines $<100 \mathrm{~m}$ long and occasionally $<1 \mathrm{~m}$ wide. Until that is possible, present sensing resolutions (Gower et al. 2006, Gower \& King 2011), with additional ground-truth data from aerial and surfacevessel surveys, may provide acceptable input for habitat-distribution modeling efforts.

In extrapolating the abundance of turtles from turtle density and Sargassum habitat area, one must consider the limitations of each data set. For example, turtle densities from distance sampling rely on an assumed value for $g(0)$. Although it seems likely that this value is close to 1 for small surface-pelagic turtles, more species- and size-specific information is needed on dive intervals and flight responses (observer effects). Using $g(0)=1$ when the actual value is $<1$ would bias density estimates on the low side. Relationships between observation distance and breadth of habitat are also important. The widely scattered Sargassum lines searched in the Gulf of Mexico gave wider ESWs in comparison to the narrower Sargassum lines searched in the Atlantic, principally near the western Gulf Stream front (Table 5). In determining which areas of Sargassum to apply to these turtle-density estimates, Sargassum at the fringes of lines should be included as well. Although habitat width likely affected our estimated ESWs, much of the habitat we surveyed was wider than ESW. We propose that a broad, high-resolution study of Sargassum habitat, coupled with distance sampling for turtles, could provide an accurate means of describing the spatial distribution of young surfacepelagic turtles. A critical aspect of the study would be to determine the most correlative Sargassum patch variable, such as biomass, area, or line length.

Anthropogenic threats to turtles within the pelagic Sargassum community include synthetic debris and petroleum. The same hydrodynamic mechanisms driving aggregation of pelagic Sargassum also drive the convergence of these buoyant pollutants (Barstow 1983). The esophageal and fecal samples we collected from surface-pelagic turtles living in Sargassum highlighted the young turtles' propensity for ingesting plastics (Table 4 and Table S1 in the supplement). In our samples, principally from juvenile green turtles and Kemp's ridleys, approximately 8 to $21 \%$ dry mass of ingested material was synthetic debris. Most of this debris was plastic. We consider this to be an alarming indicator of potential mortality. The majority of plastics we isolated from samples 
were flat, irregularly shaped shards, which we have observed in necropsies of small turtles to have a stacking effect causing blockage in the gut (B. Witherington \& S. Hirama unpubl. data). Plastic loads also would be expected to dilute the nutritional contribution of diet (McCauley \& Bjorndal 1999) and reduce somatic growth rates. Some of the ingested debris we recorded also had the potential for entanglement. One Kemp's ridley we captured had swallowed a latex balloon that trailed a synthetic ribbon $70 \mathrm{~cm}$ out from the turtle's mouth.

We observed that the frequency of entangling and ingestible plastics in the Sargassum community was high. In the convergence zones we searched, frequency of plastics appeared to be commensurate with Sargassum biomass. Most common were photodegraded pieces of larger containers, bags, and sheets. The ubiquitous nature of plastics in this surface community likely contributes to the frequency of ingestion by turtles. In esophageal lavage samples from loggerhead post-hatchlings in Gulf Stream Sargassum, Witherington (2002) found that at least 15\% of the turtles had ingested plastics. But in a sample of dead post-hatchlings stranded following storms in the same area, complete examinations of gut contents revealed a frequency of plastic ingestion approaching $100 \%$ (B. Witherington \& S. Hirama unpubl. data). Considering the limited sample of ingested material provided by lavage and fecal samples, our current frequency of plastics ingestion (67\%) is likely an underestimate.

During the 2010 BP Deepwater Horizon Oil Spill in the Gulf of Mexico, nearly 500 surface-pelagic juvenile turtles were collected/rescued from lines of oil and Sargassum within a small, accessible fraction of the total spill area (NOAA 2012a). This event clearly showed how vulnerable these small, surface-dwelling turtles are to petroleum. Much smaller and more frequent events, although less demonstrative, may be of similar importance. Burns \& Teal (1973) found that pelagic Sargassum was commonly contaminated by petroleum hydrocarbons. In our observations, we found occasional tar balls, oiled plastics, and liquid oil within convergence lines containing Sargassum. In one case, liquid oil in a Sargassum line was accompanied by a marine-engine oil filter approximately 21 in capacity, illustrating one of many sources of petroleum in this habitat.

Because of their size, behavior, and habitat, surfacepelagic post-hatchlings and juveniles are likely to be the sea turtle life stages most susceptible to petroleum. In Florida, the smallest stranded juvenile hawksbills commonly show petroleum exposure. Meylan \& Red- low (2006) reported that $22.4 \%$ of stranded hawksbills smaller than $220 \mathrm{~mm}$ SCL showed evidence of fouling by oil, and among all stranded hawksbills with evidence of oiling, $87 \%$ were $<220 \mathrm{~mm} \mathrm{SCL}$ (1980 to $2002, \mathrm{n}=45$ ). These stranded hawksbills came ashore predominantly in southeast Florida, locations closest to the Florida Current (Gulf Stream).

Mortality in surface-pelagic turtles stemming from debris ingestion, entanglement, and petroleum exposure is unlikely to be represented well by strandings. Few carcasses of these small turtles would be expected to reach shore, except under special circumstances. In addition to the distance a dead turtle would need to drift while being overlooked by scavengers, the habitat of the turtle's origin also contributes to concealment. Downwelling forces in convergence zones are known to overcome the buoyancy of many drifting items, a phenomenon that has been used to explain the lack of dead seabirds found following oil-spill mortalities (Barstow 1983).

Understanding threats to early juvenile and posthatchling sea turtles has been a critical element that is lacking in management efforts. Because these threats have diverse sources that vary over a wide geopolitical range, reducing their effects will be difficult. But measuring the rates of mortality associated with these threats is essential to determine demographic trends and assess damage from discrete catastrophic events such as major oil spills. We propose that the early surface-pelagic life stage of sea turtles is not an inaccessible one, and that further in situ studies of abundance, genetic origins, and demographic vital rates are practicable.

Acknowledgements. This work was funded by grants from the National Oceanic and Atmospheric Administration, National Marine Fisheries Service, and by revenues collected from sales of the Florida sea turtle license plate. Assistance with offshore work was provided by D. Arnold, D. Bagley, L. Bolen, J. Bogdan, M. Broadstone, K. Child, K. Frohlich, C. Koeppel, M. Lores, S. MacPherson, B. Morford, T. O'Meara, S. Smiley, B. Stacy, B. Stoll, R. Trindell, and D. Witherington. Significant ground support came from K. Jacob, A. Mosier, and K. Wendell. The manuscript benefited from reviews by J. Boyett, B. Crowder, A. Foley, R. Kiltie, K. Mansfield, and A. Meylan. Work was carried out under an NMFS Permit for Scientific Purposes under the Endangered Species Act (Permits 1198, 1506, and 14726). Photographs are credited to B. Witherington.

\section{LITERATURE CITED}

Arthur KE, Boyle MC, Limpus CJ (2008) Ontogenetic changes in diet and habitat use in green sea turtle (Chelonia mydas) life history. Mar Ecol Prog Ser 362:303-311 Barichivich WJ (2006) Characterization of a marine turtle 
aggregation in the Big Bend of Florida. MS thesis, University of Florida, Gainesville, FL

Barstow SF (1983) The ecology of Langmuir circulation: a review. Mar Environ Res 9:211-236

> Bjorndal KA, Bolten AB, Martins HR (2000) Somatic growth model of juvenile loggerhead sea turtles Caretta caretta: duration of pelagic stage. Mar Ecol Prog Ser 202:265-272

- Bjorndal KA, Bowen BW, Chaloupka M, Crowder LB and others (2011) Better science needed for restoration in the Gulf of Mexico. Science 331:537-538

Blumenthal JM, Abreu-Grobois FA, Austin TJ, Broderick $\mathrm{AC}$ and others (2009) Turtle groups or turtle soup: dispersal patterns of hawksbill turtles in the Caribbean. Mol Ecol 18:4841-4853

Bolten AB (2003a) Variation in sea turtle life history patterns: neritic versus oceanic developmental stages. In: Lutz PL, Musick JA, Wyneken J (eds) The biology of sea turtles, Vol 2. CRC Press, Boca Raton, FL, p 243-257

Bolten AB (2003b) Active swimmers-passive drifters: the oceanic juvenile stage of loggerheads in the Atlantic system. In: Bolten $A B$, Witherington $B E$ (eds) Loggerhead sea turtles. Smithsonian Books, Washington, DC, p 63-78

Bolten AB, Martins HR, Bjorndal KA, Gordon J (1993) Size distribution of pelagic-stage loggerhead sea turtles (Caretta caretta) in the waters around the Azores and Madeira. Arquipel Life Mar Sci 2A:49-54

Bowen BW, Grant WS, Hillis-Starr Z, Shaver DJ, Bjorndal KA, Bolten AB, Bass AL (2007) Mixed stock analysis reveals the migrations of juvenile hawksbills, Eretmochelys imbricata, in the Caribbean Sea. Mol Ecol 16: 49-60

Boyle MC, Limpus CJ (2008) The stomach contents of posthatchling green and loggerhead sea turtles in the southwest Pacific: an insight into habitat association. Mar Biol 155:233-241

Bresette MJ, Witherington BE, Herren RM, Bagley DA and others (2010) Size-class partitioning and herding in a foraging group of green turtles Chelonia mydas. Endang Species Res 9:105-116

Buckland ST, Anderson DR, Burnham KP, Laake JL (1993) Distance sampling: estimating abundance of biological populations. Chapman and Hall, New York, NY

Burns KA, Teal JM (1973) Hydrocarbons in the pelagic Sargassum community. Deep-Sea Res 20:207-211

Butler JN, Stoner AW (1984) Pelagic Sargassum: Has its biomass changed in the last 50 years? Deep-Sea Res 31: 1259-1264

Butler JN, Morris BF, Cadwallader J, Stoner AW (1983) Studies of Sargassum and the Sargassum community. Special Publ. No. 22, Bermuda Biological Station for Research, Ferry Reach, St. George

Camilli R, Bowen A, Yoerger DR, Whitcomb LL and others (2010) Quantifying the flow rate of the Deepwater Horizon Macondo Well oil spill. In: Proceedings of the fall meeting 2010: Abstract OS41D-05. American Geophysical Union, Washington, DC

Carr A (1986) Rips, FADS, and little loggerheads. Bioscience 36:92-100

Carr A (1987) New perspectives on the pelagic stage of sea turtle development. Conserv Biol 1:103-121

> Carr A, Meylan AB (1980) Evidence of passive migration of green turtle hatchlings in Sargassum. Copeia 1980: 366-368

Carr A, Carr MH, Meylan AB (1978) The ecology and migrations of sea turtles. 7 . The West Caribbean green turtle colony. Bull Am Mus Nat Hist 162:1-46

Chaloupka M, Zug GR (1997) A polyphasic growth function for the endangered Kemp's ridley sea-turtle, Lepidochelys kempii. Fish Bull 95:849-856

Collard SB, Ogren LH (1990) Dispersal scenarios for pelagic post-hatchling sea turtles. Bull Mar Sci 47:233-243

Coston-Clements L, Dettle LR, Hoss DE, Cross FA (1991) Utilization of the Sargassum habitat by marine invertebrates and vertebrates: a review. NOAA Tech Memo NMFS-SEFSC 296:1-32

Dooley JK (1972) Fishes associated with the pelagic Sargassum complex, with a discussion of the Sargassum community. Contrib Mar Sci 16:1-32

Ehrhart LM (1980) Threatened and endangered species of the Kennedy Space Center: marine turtle studies. Contract Report 163122 to NASA Kennedy Space Center, Biomedical Office MD-B. KSCTR 51-2, University of Central Florida, Orlando, FL Available at http://ntrs. nasa.gov/archive/nasa/casi.ntrs.nasa.gov/19800023462_ 1980023462.pdf

Forbes GA (1999) Diet sampling and diet component analysis. In: Eckert KL, Bjorndal KA, Abreu-Grobois FA, Donnelly $M$ (eds) Research and management techniques for the conservation of sea turtles. IUCN/SSC Marine Turtle Specialist Group Publication, Washington, DC, p 144-148

Garduño-Andrade M (1999) Nesting of the hawksbill turtle, Eretmochelys imbricata, Río Lagartos, Yucatán, Mexico, 1990-97. Chelonian Conserv Biol 3:281-285

Goshe LR, Avens L, Scharf FS, Southwood AL (2010) Estimation of age at maturation and growth of Atlantic green turtles (Chelonia mydas) using skeletochronology. Mar Biol 157:1725-1740

Gower JFR, King SA (2011) Distribution of floating Sargassum in the Gulf of Mexico and the Atlantic Ocean mapped using MERIS. Int J Remote Sens 32:1917-1929

> Gower J, Hu C, Borstad G, King S (2006) Ocean color satellites show extensive lines of floating Sargassum in the Gulf of Mexico. IEEE Trans Geosci Rem Sens 44: 3619-3625

Hasbún CR (2002) Observations on first day dispersal of neonatal hawksbill turtles (Eretmochelys imbricata). Mar Turtle Newsl 96:7-10

Hay ME (1986) Associational plant defenses and the maintenance of species diversity: turning competitors into accomplices. Am Nat 128:617-641

Higgins BM (2003) Sea turtle husbandry. In: Lutz PL, Musick JA, Wyneken J (eds) The biology of sea turtles, Vol 2. CRC Press, Boca Raton, FL, p 411-440

> Hochscheid S, Godley BJ, Broderick AC, Wilson RP (1999) Reptilian diving: highly variable dive patterns in the green turtle Chelonia mydas. Mar Ecol Prog Ser 185: 101-112

Hornell J (1927) The turtle fisheries of the Seychelles Islands. His Majesty's Stationery Office, London

$>$ Houghton JDR, Broderick AC, Godley BJ, Metcalfe JD, Hays GC (2002) Diving behaviour during the internesting interval for loggerhead turtles, Caretta caretta nesting in Cyprus. Mar Ecol Prog Ser 227:63-70

> Howell EA, Kobayashi DR, Parker D, Balazs GH, Polovina JJ (2008) TurtleWatch: a tool to aid in the bycatch reduction of loggerhead turtles Caretta caretta in the Hawaii-based pelagic longline fishery. Endang Species Res 5:267-278

Howell EA, Dutton PH, Polovina JJ, Bailey H, Parker DM, Balazs GH (2010) Oceanographic influences on the dive 
behavior of juvenile loggerhead turtles (Caretta caretta) in the North Pacific Ocean. Mar Biol 157:1011-1026

> Hu C (2009) A novel ocean color index to detect floating algae in the global oceans. Remote Sens Environ 113: 2118-2129

Kobayashi DR, Polovina JJ, Parker DM, Kamezaki N and others (2008) Pelagic habitat characterization of loggerhead sea turtles, Caretta caretta, in the North Pacific Ocean (1997-2006): insights from satellite tag tracking and remotely sensed data. J Exp Mar Biol Ecol 356: 96-114

Kraemer JE, Bennett SH (1981) Utilization of posthatching yolk in loggerhead sea turtles, Caretta caretta. Copeia 1981:406-411

Lohmann K, Lohmann C (1996) Orientation and open-sea navigation in sea turtles. J Exp Biol 199:73-81

Manooch CS III, Mason DL, Nelson RS (1984) Food and gastrointestinal parasites of dolphin Coryphaena hippurus collected along the southeastern and Gulf coasts of the United States. Bull Jpn Soc Sci Fish 50:1511-1525

Mansfield KL, Saba VS, Keinath J, Musick JA (2009) Satellite telemetry reveals a dichotomy in migration strategies among juvenile loggerhead sea turtles in the northwest Atlantic. Mar Biol 156:2555-2570

Marquez MR (1994) Synopsis of biological data on the Kemp's ridley turtle Lepidochelys kempi (Garman, 1880). NOAA Tech Memo NMFS-SEFSC 343:1-91

> McCarthy AL, Heppell S, Royer F, Freitas C, Dellinger T (2010) Identification of likely foraging habitat of pelagic loggerhead sea turtles (Caretta caretta) in the North Atlantic through analysis of telemetry track sinuosity. Prog Oceanogr 86(Spec Issue):224-231

> McCauley SJ, Bjorndal KA (1999) Conservation implications of dietary dilution from debris ingestion: sublethal effects in post-hatchling loggerhead sea turtles. Conserv Biol 13:925-929

McClellan CM, Read AJ (2007) Complexity and variation in loggerhead sea turtle life history. Biol Lett 3:592-594

McMichael E, Carthy RR, Seminoff JA (2006) Ecology of juvenile sea turtles in the northeastern Gulf of Mexico. In: Pilcher NJ (ed) Proceedings of the 23rd annual symposium on sea turtle biology and conservation. NOAA Tech Memo NMFS-SEFSC 536:20-21

Mellgren RL, Mann MM, Bushong ME, Harkins SR, Keathley VL (2003) Habitat selection and antipredator behavior in three species of hatchling sea turtles. Int J Comp Psychol 16:156-171

Meylan A, Redlow A (2006) Eretmochelys imbricatahawksbill turtle. In: Meylan PA (ed) Biology and conservation of Florida turtles. Chelon Res Monogr 3:105-127

- Meylan PA, Meylan AB, Gray JA (2011) The ecology and migrations of sea turtles. 8. Tests of the developmental habitat hypothesis. Bull Am Mus Nat Hist 357:1-70

Musick JA, Limpus CJ (1997) Habitat utilization and migration in juvenile sea turtles. In: Lutz PL, Musick JA (eds) The biology of sea turtles, Vol 1. CRC Press, Washington, DC, p 137-163

NOAA (National Oceanic and Atmospheric Administration) (2012a) Sea turtles and the Gulf of Mexico oil spill. Available at: www.nmfs.noaa.gov/pr/health/oilspill/turtles. htm (accessed 19 July 2012)

NOAA (National Oceanic and Atmospheric Administration) (2012b) Coastwatch, Caribbean/Gulf of Mexico regional node. Available at: http://cwcaribbean.aoml.noaa.gov/ data.html (accessed 19 July 2012)
Parker DM, Dutton PH, Balazs GH (2011) Oceanic diet and distribution of haplotypes for the green turtle, Chelonia mydas, in the Central North Pacific. Pac Sci 65:419-431

Plotkin PT (1999) Feeding ecology of the loggerhead sea turtle in the northwestern Gulf of Mexico. In: Eckert SA, Eckert KL, Richardson TH (eds) Proceedings of the 9th annual workshop on sea turtle conservation and biology. NOAA Tech Memo NMFS-SESC 232:139-141

Plotkin PT (ed) (2007) Biology and conservation of Ridley sea turtles. Johns Hopkins University Press, Baltimore, MD

Polovina JJ, Kobayashi DR, Parker DM, Seki MP, Balazs GH (2000) Turtles on the edge: movement of loggerhead turtles (Caretta caretta) along oceanic fronts, spanning longline fishing grounds in the central North Pacific, 1997-1998. Fish Oceanogr 9:71-82

Polovina JJ, Howell E, Parker DM, Balazs GH (2003) Divedepth distribution of loggerhead (Caretta caretta) and olive ridley (Lepidochelys olivacea) sea turtles in the central North Pacific: Might deep longline sets catch fewer turtles? Fish Bull 101:189-193

> Polovina JJ, Balazs GH, Howell EA, Parker DM, Seki MP, Dutton PH (2004) Forage and migration habitat of loggerhead (Caretta caretta) and olive ridley (Lepidochelys olivacea) sea turtles in the central North Pacific Ocean. Fish Oceanogr 13:36-51

> Polovina J, Uchida I, Balazs GH, Howell EA, Parker D, Dutton P (2006) The Kuroshio Extension Bifurcation Region: a pelagic hotspot for juvenile loggerhead sea turtles. Deep-Sea Res II 53:326-339

> Reich KJ, Bjorndal KA, Bolten AB (2007) The 'lost years' of green turtles: using stable isotopes to study cryptic life stages. Biol Lett 3:712-714

Richardson JI, McGillivary P (1991) Post-hatching loggerhead turtles eat insects in Sargassum community. Mar Turtle Newsl 55:2-5

Russell DJ, Hargrove S, Balazs GH (2011) Marine sponges, other animal food, and nonfood items found in digestive tracts of the herbivorous marine turtle Chelonia mydas in Hawai'i. Pac Sci 65:375-381

Schmid JR (1998) Marine turtle populations on the westcentral coast of Florida: results of tagging studies at the Cedar Keys, Florida, 1986-1995. Fish Bull 96:589-602

Schroeder BA, Foley AM, Witherington BE, Mosier AE (1998) Ecology of marine turtles in Florida Bay: population structure, distribution, and occurrence of fibropapilloma. In: Epperly SP, Braun J (eds) Proceedings of the 17 th annual sea turtle symposium. NOAA Tech Memo NMFS-SEFSC 415:265-267

> Seminoff JA, Jones TT, Marshall GJ (2006) Underwater behaviour of green turtles monitored with video-timedepth recorders: what's missing from dive profiles? Mar Ecol Prog Ser 322:269-280

Seney EE (2008) Population dynamics and movements of the Kemp's ridley sea turtle, Lepidochelys kempii, in the northwestern Gulf of Mexico. PhD dissertation, Texas A\&M University, College Station, TX

Shaver DJ (1991) Feeding ecology of wild and head-started Kemp's ridley sea turtles in South Texas waters. J Herpetol 25:327-334

Smith MM, Salmon M (2009) A comparison between the habitat choices made by hatchling and juvenile green turtles (Chelonia mydas) and loggerheads (Caretta caretta). Mar Turtle Newsl 126:9-13

Thiel M, Gutow L (2005a) The ecology of rafting in the 
marine environment. I. The floating substrata. Oceanogr Mar Biol Annu Rev 42:181-263

Thiel M, Gutow L (2005b) The ecology of rafting in the marine environment. II. The rafting organisms and community. Oceanogr Mar Biol Annu Rev 43:279-418

Thomas L, Laake JL, Rexstad E, Strindberg S and others (2009) Distance 6.0, Release 2. Research Unit for Wildlife Population Assessment, University of St. Andrews, St. Andrews. Available at: www.ruwpa.st-and.ac.uk/distance/

Tomas JF, Aznar J, Raga JA (2001) Feeding ecology of the loggerhead turtle Caretta caretta in the western Mediterranean. J Zool (Lond) 255:525-532

USGS (United States Geological Survey) (2012) USGS global visualization viewer. Available at: http://glovis. usgs.gov/ (accessed 19 July 2012)

Weimerskirch H (2007) Are seabirds foraging for unpredictable resources? Deep-Sea Res II 54:211-223

Williams BK, Nichols JD, Conroy MJ (2002) Analysis and management of animal populations. Academic Press,

Editorial responsibility: Hans Heinrich Janssen, Oldendorf/Luhe, Germany
San Diego, CA

> Witherington BE (2002) Ecology of neonate loggerhead turtles inhabiting lines of downwelling near a Gulf Stream front. Mar Biol 140:843-853

Witherington B, Herren R, Bresette M (2006) Caretta caretta-Loggerhead sea turtle. In: Meylan PA (ed) Biology and conservation of Florida turtles. Chelon Res Monogr 3:74-89

Witherington B, Kubilis P, Brost B, Meylan A (2009) Decreasing annual nest counts in a globally important loggerhead sea turtle population. Ecol Appl 19:30-54

Witzell WN, Schmid JR (2004) Immature sea turtles in Gullivan Bay, Ten Thousand Islands, Southwest Florida. Gulf Mex Sci 1:54-61

Wyneken J (1997) Sea turtle locomotion: mechanics, behavior, and energetics. In: Lutz PL, Musick JA (eds) The biology of sea turtles. CRC Press, Boca Raton, FL, p 165-198

> Wyneken J, Salmon M (1992) Frenzy and postfrenzy swimming activity in loggerhead, green, and leatherback hatchling sea turtles. Copeia 1992:478-484

Submitted: May 23, 2012; Accepted: July 27, 2012

Proofs received from author(s): August 23, 2012 